Historic, Archive Document

Do not assume content reflects current scientific knowledge, policies, or practices. 



\section{GRISWOLD'S Annual Seed Catalogue for 1909}

\section{HIGHEST GRADE

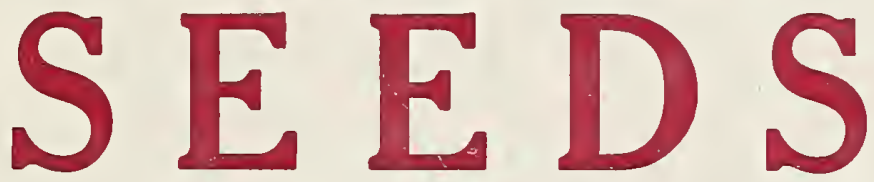 \\ At Lowest Cash Prices}

A Catalogue direct from SEED GROWERS to SEED PLANTERS.

Compare our prices with prices of other reliable Seed Men. : : : : : :

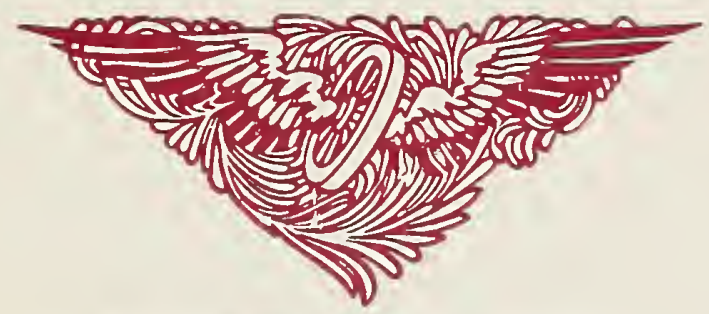

PIONEER SEED FIRM.

Business Established 1845

\section{THOS. GRISWOLD \& CO. SOUTH WETHERSFIELD, CONN.}




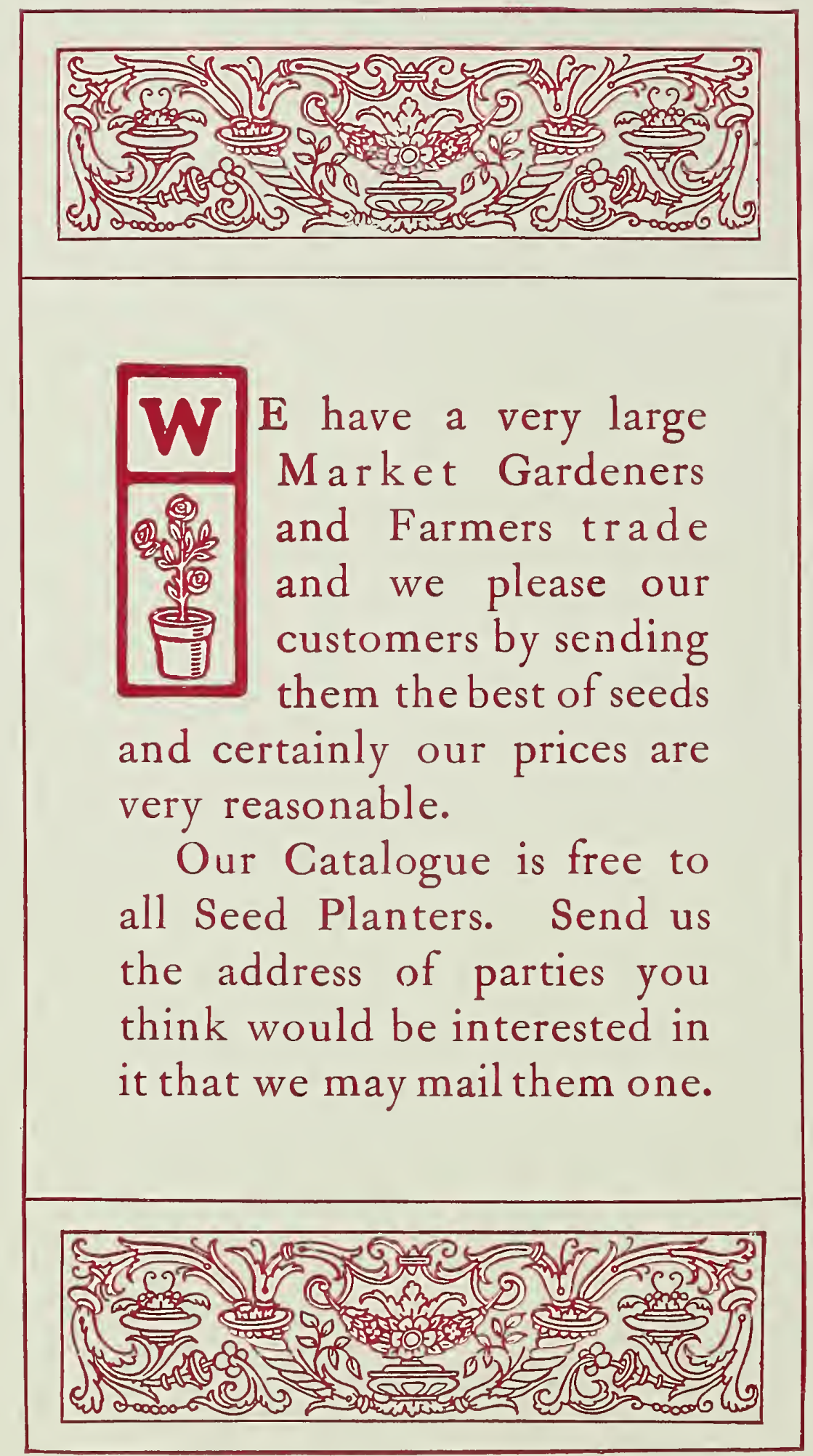




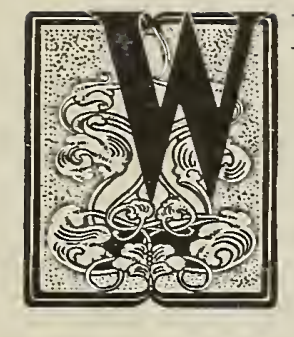

$E$ have one of the finest Market Gardeners and Farmers trade in the country and we wish to increase it 25,000 new customers this year. Our firm has been in the seed growing business for over sixty years, formerly growing seeds exclusively for the wholesale trade. About twenty years ago we started a Market Gardeners and Farmers trade, selling direct to the seed planter, and our business in this line has increased so rapidly that we have practically given up our wholesale trade and are now giving nearly our entire attention to this Market Gardeners and Farmers trade.

We plant many seeds ourselves and we realize that the seed planter wants the very best seeds he can purchase as it certainly pays no one to plant poor seeds, and he wants the best at reasonable prices. This year we have cut out all discounts, etc., and make very low cash prices for first class seeds. We ask you to compare our prices with the prices of other reliable seedmen.

Our office and buildings are on our own seed farms which makes our business expenses comparatively light and we do not spend large sums of money for advertisements and fancy catalogues, but send out this plain catalogue of best of seeds, at low cash prices. Now if you use seeds, no matter whether in small or large quantities, please look through this catalogue carefully, make out an order and send it to us and we will do the best we can to please you.

We take this opportunity to thank our many customers for their liberal patronage in the past and trust that we shall continue to receive their favors.

Respectfully yours,

THOMAS GRISWOLD \& CO. 


\section{W A N T E D}

IF YOU ARE A MARKET GARDENER, FARMER OR HAVE ONLY A PRIVATE GARDEN, YOU WANT THE BEST SEEDS PROCURABLE AND WE WANT YOU AS OUR CUSTOMER.

Send us your order, we feel sure our seeds will, give you entire satisfaction.

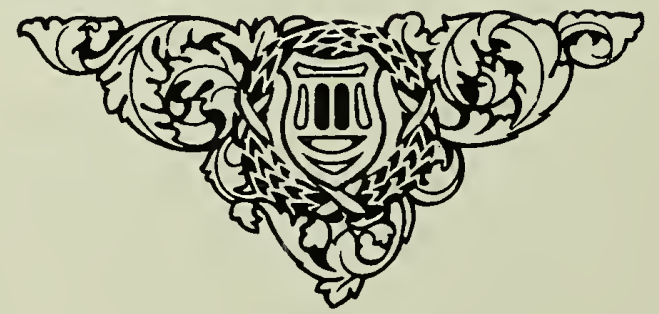




\section{OFFICE OF \\ THOMAS GRISWOLD \& CO., \\ South Wethersfield, Conn.}

January 15, 1909.

\section{TERMS.}

We make our prices so low that we can afford to give credit only to reliable parties well known to us and only in limited amounts, and when credit is allowed interest at the rate of six per cent. per annum will be added. By doing principally a cash with order business we run little risk and can make very reasonable prices which is a benefit to our customers. Out-standing bills are due June Ist, I909, unless otherwise agreed.

How to send money.-Remit by Post Office or Express Money Order, Registered Mail or Bank Draft. Postage Stamps may be sent for small amounts. Personal Checks accepted from parties having established credit.

Post Office Money Orders should be made payable at South Wethersfield.

When Seeds are Wanted by Mail, postage must be added at the rate of 8 cents per pound for Seeds, (except flower seeds), ro cents per quart for Corn and Onion Sets, and 15 cents per quart for Beans and Peas.

Bags, barrels, etc., free of charge. No charge for cartage.

Purchasers pay express and freight charges unless otherwise agreed.

Shipping Instructions should accompany each order. If no such instructions are received we will ship by the best and cheapest route known to us.

After shipping in good order our responsibility ceases, claims for damages or miscarriage must be laid on the carriers.

Parties purchasing from us, and wishing references as to our business integrity are respectfully referred to R. G. Dun \& Co's, and Bradstreet's Mercantile Agencies, also to our Postmaster, or Town Officers.

As so much depends upon the condition of the weather, soil, etc., when seeds are planted, and the care taken in planting them, we sell our goods, in common with other reliable seed houses, subject to the following disclaimer adopted by the American Seed Trade Association.

Disclaimer,-We give no warranty, express or implied as to description, quality, productiveness or any other matter of any seeds, bulbs or plants we send out and will not be in any way responsible for the crop. If the purchaser does not accept the goods on these terms they are at once to be returned. 


\section{ASPARAGUS.}

Conover's Colossal. A standard variety,

Barr's Philadelphia Mammoth. Large, uniform and tender,

Palmetto. Early, large, bright green,

\section{BEANS. - Dwarf Green Podded.}

Extra Early Refugee. Two weeks earlier than the common Refugee, more Dwarf, and compact in habit of growth, pods whitish green, round and tender,

Early Long Yellow, Six Weeks. Early, light green, straight, flat pod,

Improved Early Round Pod Valentine. Good, extra early, green pod,

Stringless, Green Pod(Burpee's). Early, productive, very hardy,

Low's Champion. Green podded, large, very prolific,

Refugee or Thousand To One. Old standard, medium early, .

Dwarf Horticultural. Yellowish pod, splashed with red; excellent,

Goddard or Boston Favorite. Large vines, long, large, flat pods; green, crimson striped,

White Kidney. I5

. Excellent for cooking, when dry,

Henderson's Bush Lima. A small, low lima,.

Burpee's Bush Lima. Dwarf vine ; large flat beans,

Thorburn's or Dreer's Bush Lima. Roundish white beans; fine quality,

\section{Wax or Butter Varieties.}

Golden Eyed Wax. White bean with yellow eye; early and hardy, pods long, straight, flat, fair quality,

Improved Rust Proof Golden Wax. Improved strain of Golden Wax, pods straight, flatish, golden yellow color, .

Currie's Rust Proof Black Wax. Yellow, flat pods; hardy and early,

Prolific Black Wax. More productive than common Black Wax,

Dwarf German Black Wax. Round yellow pods; early and tender,

Challenger Black Wax. Improved strain of Black Wax, .

Wardwell's Kidney Wax. Large, flat, yellow pod, and early,

Refugee Wax. A very productive yellow podded variety,

Yosemite Mammoth Black Wax. Mammoth, long, yellow pods, fine quality,

Davis' White Kidney Wax. Extremely hardy and good keeping quality,

Valentine Wax. Round, meaty, yellow pods, excellent, .

\section{Pole or Running Varieties.}

Early Dutch Case Knife. Very early; flat, green pod, . . Horticultural or Cranberry Pole. Long, green pod; red striped, Extra Early Jersey Lima. One of the best early limas, .

Siebert's Early, large lima, similar to the above, but larger pods,

King of Garden Lima. Early, productive, large podded variety,

Extra Large Lima. Very large, late lima, 


\section{Pole or Running Varieties.-Continued.}

Lazy Wife. Small, white pole beans, green pods, tender and rich,

Kentucky Wonder (Old Homestead), Stringless. Long bright green pods: tender; grow in clusters and very productive.

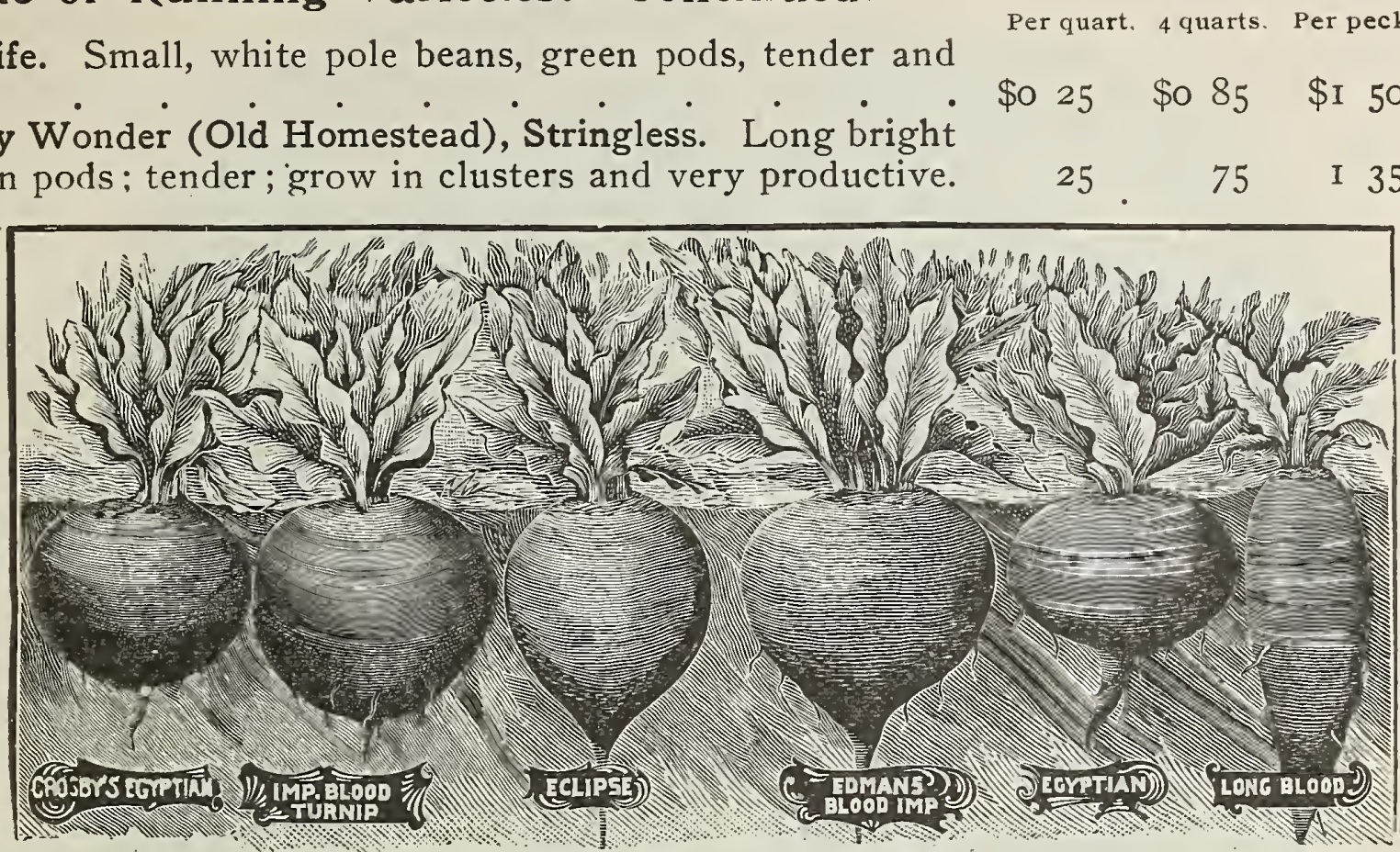

Per bu.

$\$ 550$

500

\section{BEETS. - Garden Varieties.}

Crosby's Egyptian Turnip. Improved strain of the Old Egyptian; thicker beet,

Early Egyptian Turnip. Quick growing flat variety,

Early Eclipse. Smallish. round, red beet; excellent,

Columbia (Burpee's). Round, deep red; fine quality,

Detriot Dark Red. Early, small tops, dark red,

Extra Early Dirigo. One of the earliest; fine quality,

Early Crimson Globe. Very early, globe shape; flesh deep purple,

Edmand's Early Turnip. The best for late planting; blood red and sweet,

Swiss Chard. For greens,

Extra Early Bassano. A good variety,

Arlington Early Blood Turnip. An excellent strain of blood turnip,

Improved Early Blood Turnip. Improvement on the old strain, fine stock, .

Bastian's Early Blood Turnip. A good, extra early strain,

Long, smooth, Dark Red. Fine grained, long deep red beet,

\section{MANGEL BEETS.-For Stock Feeding.}

Red Globe Mangel. Medium size, globe shape,

Long Red Mangel. One of the best for stock, .

Mammoth Long Red Mangel. Very large, great yielder

Golden Tankard. Short, thick, yellow mangel,

Yellow Globe Mangel. Not very large, good quality

French White Sugar. A good small beet for stock, sweet,

Lane's White Sugar. Improvement on French White Sugar, .

\begin{tabular}{|c|c|c|c|c|c|}
\hline \multirow{2}{*}{$\begin{array}{l}\text { Per oz. } \\
\text { \$o } 05\end{array}$} & \multicolumn{2}{|c|}{ Per $1 / 4 \mathrm{lb}$. } & Per $1 \mathrm{~b}$. & \multicolumn{2}{|c|}{$\begin{array}{c}5 \text { lbs. } \\
\text { or more } \\
\text { Per } 1 \mathrm{lb} \text {. }\end{array}$} \\
\hline & \$o & I 5 & $\$ 0 \quad 50$ & \$o & 45 \\
\hline 5 & & I 5 & 35 & & 32 \\
\hline 5 & & I 5 & 35 & & 32 \\
\hline 5 & & I 5 & 40 & & 35 \\
\hline 5 & & I 5 & 40 & & 35 \\
\hline 5 & & I 5 & 40 & & 35 \\
\hline 5 & & I 5 & 50 & & 45 \\
\hline 5 & & I 5 & 40 & & 35 \\
\hline 5 & & I 5 & 32 & & $3 c$ \\
\hline 5 & & I2 & 30 & & 28 \\
\hline 5 & & 12 & 30 & & 28 \\
\hline 5 & & 12 & 25 & & 22 \\
\hline & & I2 & 30 & & 28 \\
\hline 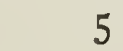 & & 12 & 30 & & $2 !$ \\
\hline
\end{tabular}

5

$\begin{array}{ll}10 & 20 \\ 10 & 20 \\ 10 & 20 \\ 10 & 20 \\ 10 & 20 \\ 10 & 20 \\ 10 & 20\end{array}$

\section{BRUSSELS SPROUTS.}

Paris Market. Dwarf variety, excellent, .

Long Island Strain. Favorite in New York market. 


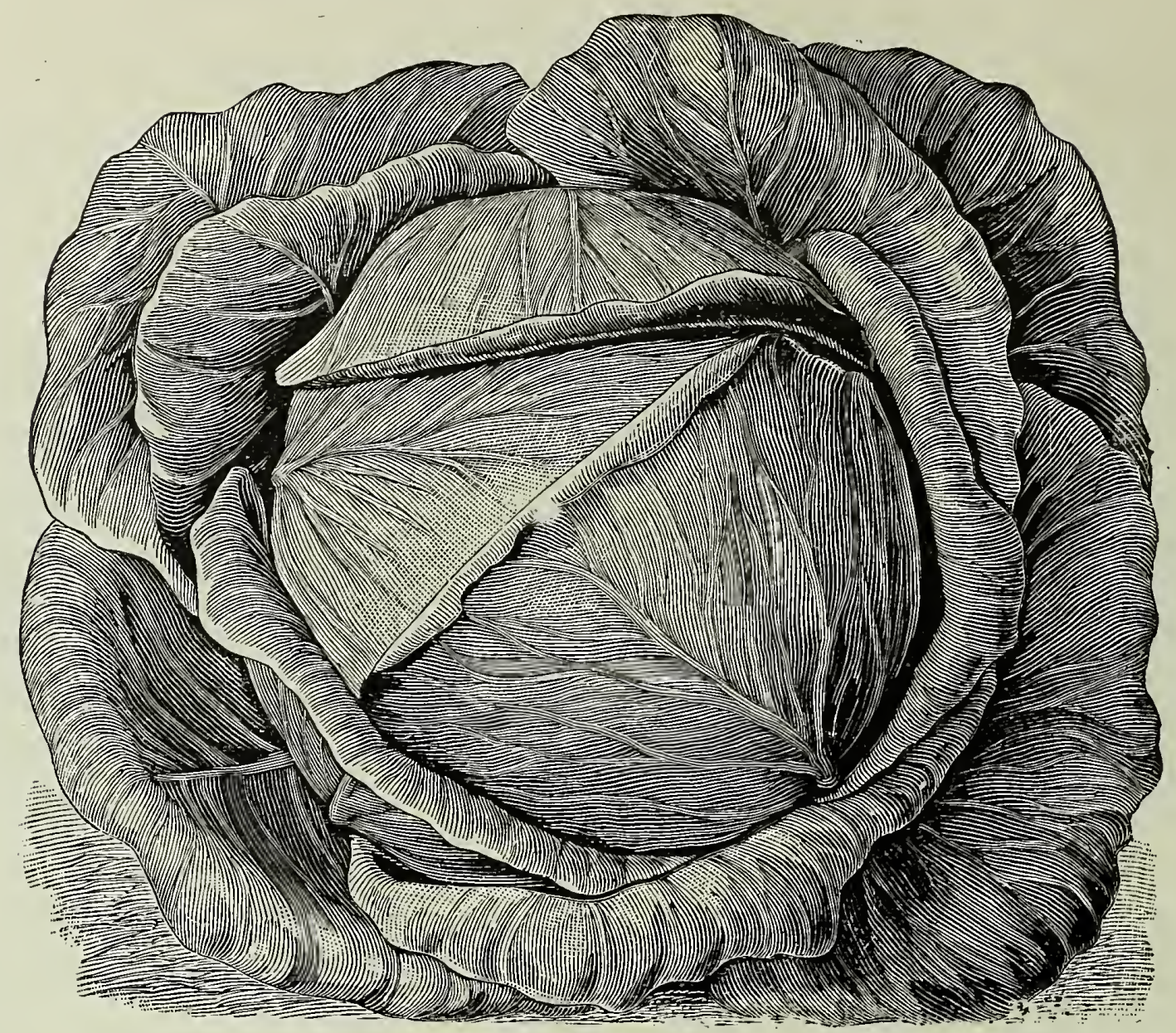

CABBAGE.

Our Danish Ball Head, Red Dutch and Winningstadt Cabbage are best imported stocks, and all other varieties are finest strains, Long Island grown, the Home of the Cabbage.

Extra Early Express. A small, extra early cabbage, pointed -head,

Early Etamps. Quite similar to the above, head more sharply pointed,

Early Spring. The earliest flat head variety, and large, .

Early Jersey Wakefield. 'A fair size. . Early, peaked head, .

Large Jersey Wakefield or Charleston. Larger than the Early Jersey Wakefield,

Early Winningstadt. Small pointed head, imported cabbage,

Early Flat Dutch. A very popular early flat head sort, . .

Henderson's Early Summer. Similar to Early Flat Dutch, .

All Head. Early, large, flat head cabbage,

Henderson's Succession. A good second early flat head sort,

Fottler's Improved Brunswick. Old reliable standard flat head,

Surehead. Large, uniform, solid head; sure header,

All Seasons or Vandergaw. Fine, large, quick heading sort, .

The Lupton. Improved All Season, .

Premium Late Flat Dutch. The old popular variety, for autumn and winter,

Autumn King or World Beater. Very large solid heads, .

Half Dwarf Danish Ball Head or Hollander. Very hard, small, round head. Excellent keeper,

Dwarf Danish Ball Head. Stems dwarfer, heads larger and little flatter than the Half Dwarf. A good winter variety,

Volga. Round, solid, uniform head; medium late, fine strain,

\begin{tabular}{|c|c|c|c|}
\hline Per oz. & Per $1 / 4 \mathrm{lb}$. & Per 1b. & $\begin{array}{l}5 \mathrm{lbs} \text {. } \\
\text { or more } \\
\text { Per llb. }\end{array}$ \\
\hline IO & \$o 30 & $\$ I \infty$ & $\$ 090$ \\
\hline IO & 30 & I 00 & no \\
\hline I 5 & 45 & I 75 & I 60 \\
\hline 20 & 50 & I 90 & I 80 \\
\hline 20 & 50 & I 90 & I 80 \\
\hline IO & 30 & I 00 & 90 \\
\hline I 5 & 40 & I 50 & I 40 \\
\hline I 5 & 40 & I 50 & I 40 \\
\hline I 5 & 45 & I 60 & I 50 \\
\hline I 5 & 45 & I 60 & I 50 \\
\hline 15 & 35 & I 30 & I 20 \\
\hline I 5 & 45 & I 60 & I 50 \\
\hline I 5 & 45 & I 60 & I 50 \\
\hline I 5 & 45 & I 60 & I 50 \\
\hline IO & 35 & I 30 & I 20 \\
\hline I 5 & 40 & I 40 & I 30 \\
\hline I 5 & 45 & I 75 & I 60 \\
\hline I 5 & 45 & I 75 & I 60 \\
\hline 20 & 60 & 200 & I 90 \\
\hline
\end{tabular}




\section{CABBAGE-Continued.}

Red Dutch Pickling. A hard headed, red pickling cabbage, Mammoth Red Rock. Larger than Red Dutch, •

Perfection Drumhead Savoy. Large, crisp and tender head, curled or crumpled leaves,

\section{CARROT.}

Early Scarlet Horn. A short, early variety,

Ox-Heart or Guerande. One of the earliest, heart shape,
Improved Long Orange. The old standard, more for stock feeding,

Improved Danvers Orange. Excellent, stump-rooted sort, .

Danvers Half Long Pointed. Medium long, scarlet, tapering root,

James Intermediate. Very similar to Danvers Half Long, .

Half Long Nantes. Stump-rooted, little smaller than Improved Danvers,

Chantenay. A short chunked carrot, good for table,

Rubicon. Fine, half-long market variety,

\section{CAULIFLOWER. - Selected.}

Henderson's Early Snowball. One of the best for market,

\$o Per oz. Per $1 / 41 \mathrm{~b}$. Per $1 \mathrm{~b}$.

IO

15

I 5
$51 \mathrm{~b}$. or more Per $1 \mathrm{~b}$. \$o 90 I 40

I 50

45 45

35

40

40

40

45

45

50

\begin{tabular}{|c|c|c|c|}
\hline $\begin{array}{l}\text { Per } 1 / 4 \text { oz. } \\
\text { So }\end{array}$ & $\begin{array}{l}\text { Per } 1 / 2 \text { oz. } \\
\text { So } 05\end{array}$ & $\begin{array}{l}\text { Per oz. } \\
\$ 175\end{array}$ & $\begin{array}{l}\text { Per } 1 / 1 b \\
\$ 6\end{array}$ \\
\hline 40 & 75 & I 30 & \\
\hline 25 & 40 & 60 & 2 \\
\hline 20 & 35 & 55 & 2 \\
\hline 25 & 40 & 60 & \\
\hline
\end{tabular}

Extra Early Dwarf Erfurt. Early, of dwarf habit, excellent, .

Le Normand's Short Stem. Large, close heads,

Early Paris. Good quality, medium large heads,

Algiers. Vigorous growth, large head, late,

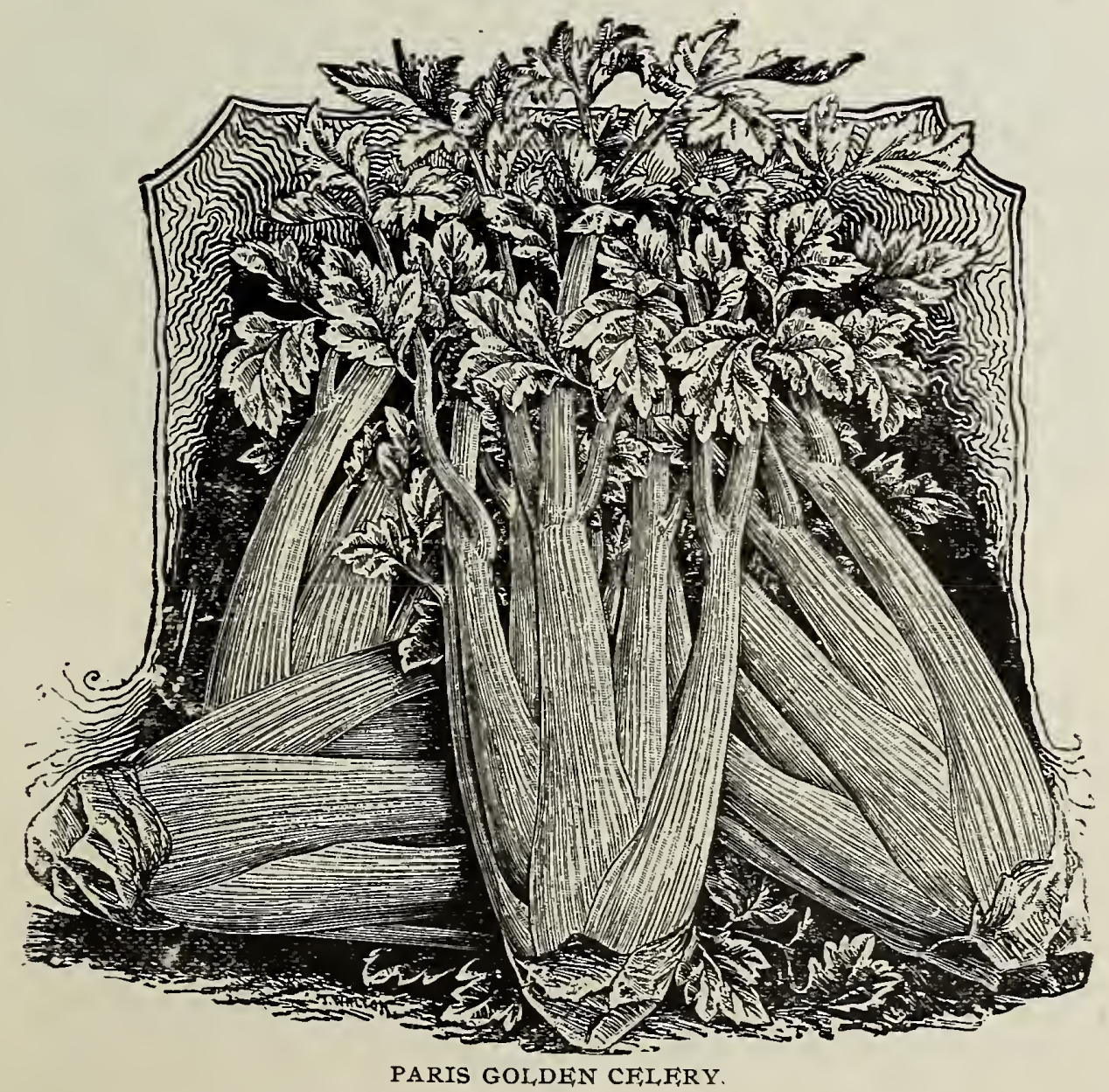

CELERY.

Paris Golden. Self blanching. Finest French grown. (Originators stock).

We import this strain direct from the originators in Paris and highly recommend

it. Per 0z., 25c., per $1 / 4 \mathrm{lb}, 85 \mathrm{c}$., per lb., $\$ 3.00,5 \mathrm{lbs}$. or more, $\$ 2.75$ per $1 \mathrm{~b}$. 


\section{CELERY - Continued。}

White Plume. Self bleaching, .

Giant $P_{d a s c a l}$. Excellent green variety, crisp and tender, fine keeper, • • • • • • • • •

Perfection Heartwell. Golden yellow hearted, superior quality, Golden Heart Dwarf. Old standard, fine flavor,
Crawford's or Henderson's Half Dwarf. Medium size, yellowish white,

Boston Market. One of the old reliable sorts,

Shumacher. Very large yellow heart, nutty flavor, crisp,

Winter Queen. Finest winter variety, long keeper,

Celeriac. Large, smooth sprague, turnip-rooted-celery, .

\begin{tabular}{|c|c|c|c|c|}
\hline $\begin{array}{l}\text { Per oz. } \\
\text { \$o I } 5\end{array}$ & $\begin{array}{l}\text { Per } 1 / 4 \mathrm{lb} \text {. } \\
\$ 040\end{array}$ & $\begin{array}{l}\text { Per 1b. } \\
\$ \text { I } 40\end{array}$ & $\begin{array}{r}51 \\
\text { or } \\
\text { Pet } \\
\text { Pet } \\
\$ I\end{array}$ & $\begin{array}{l}\begin{array}{l}\text { bs. } \\
\text { more } \\
\text { t } 1 \mathrm{~b} . \\
30\end{array} \\
\text {. }\end{array}$ \\
\hline IO & 30 & I 00 & & 90 \\
\hline IO & 30 & I 00 & & 90 \\
\hline IO & 30 & I $\infty$ & & 90 \\
\hline IO & 30 & I 00 & & 90 \\
\hline IO & 30 & I OO & & 90 \\
\hline I5 & 35 & I 25 & I & 15 \\
\hline I 5 & 35 & I 25 & I & 15 \\
\hline IO & 30 & I. vo & & 90 \\
\hline
\end{tabular}

\section{CORN SALAD.}

Broad Leaved. A good substitute for lettuce in winter, .

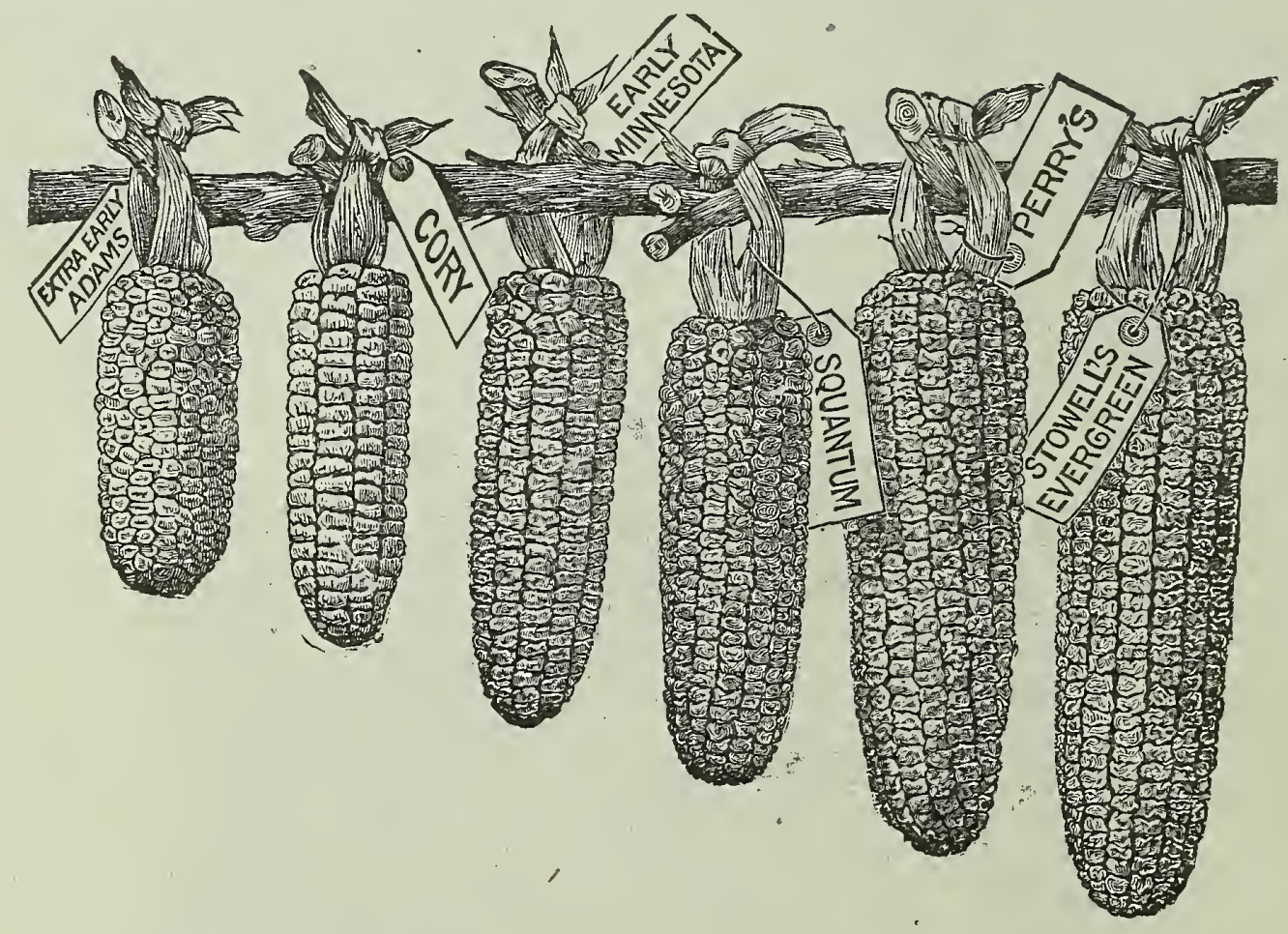

\section{SWEET CORN.}

There is no Sweet Corn grown that will equal in quality the Corn grown in New England. Our Stock is fine.

Golden Bantam. A beautiful golden yellow variety of fine, sweet flavor, very early, productive and excellent quality, and is fast coming to the front where known, . . .

Extra Early Red Cory. Very early, large kernel, medium size red cob, .

Extra Early White Cory. Like the above only white,

Burbank's Early Maine. Improved White Cory,

Mammoth White Cory. About as early and larger than White Cory

Cosmopolitan. One of the best Early Large Eared varieties,

Early Minnesota. Early variety and good quality, .

Early Metropolitan. Large, second early, white ears, Io to 12 inches,

Early Champion. Large ear, white grain, early, market gardener's favorite,

Crosby's Early. No better corn grows, for second early,

Perry's Hybrid. Sweet, tender, good sized ear, second early, .
Per quart. 4 quarts. Per peck. Per bu.
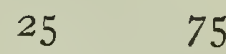

I 35

500

20

20

20

20

20

20

20 


\section{SWEET CORN.-Continued.}

Black Mexican. Black kernel, fair sized ear, second early, fine quality,

Russell's Prolific. Medium early of excellent quality, .

Excelsior Sugar Twelve Rowed. Similar to Russell's Prolific,

Moore's Early Concord. Thick ear, good size, fine quality, .

Early Evergreen. About Io days earlier than Stowell's Evergreen,

Potter's Excelsior or Squantum. Second early, very sweet, .

Early Mammoth. Long, slim ear, about two weeks earlier than Late Mammoth, .

Stowell's Evergreen. Old and tried variety,

Shoe Peg. Long, slim kernel, ears medium size, very sweet; late,

Country Gentleman. Little larger than Shoe Peg, .

Late Mammoth. Very large white ears and late,

For Field and Ensilage Corn, see pages 22 and 23.

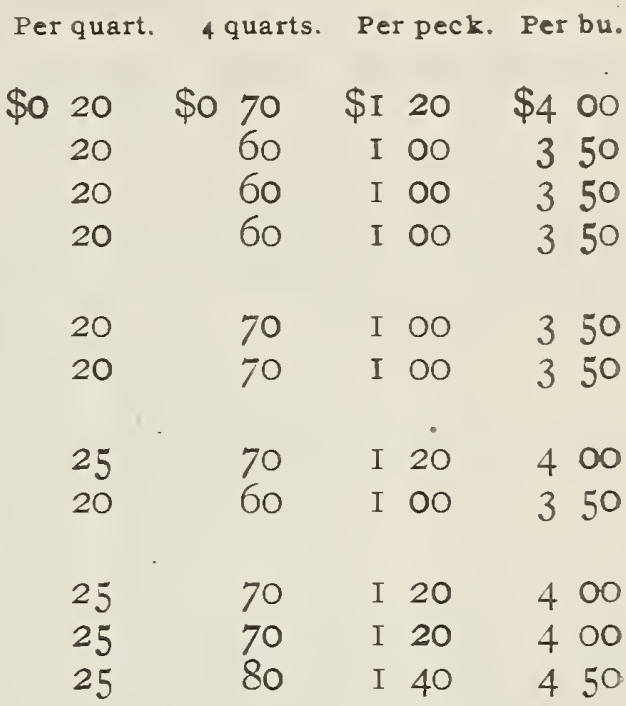

\section{CRESS.}

Extra Curled. Quick growing,

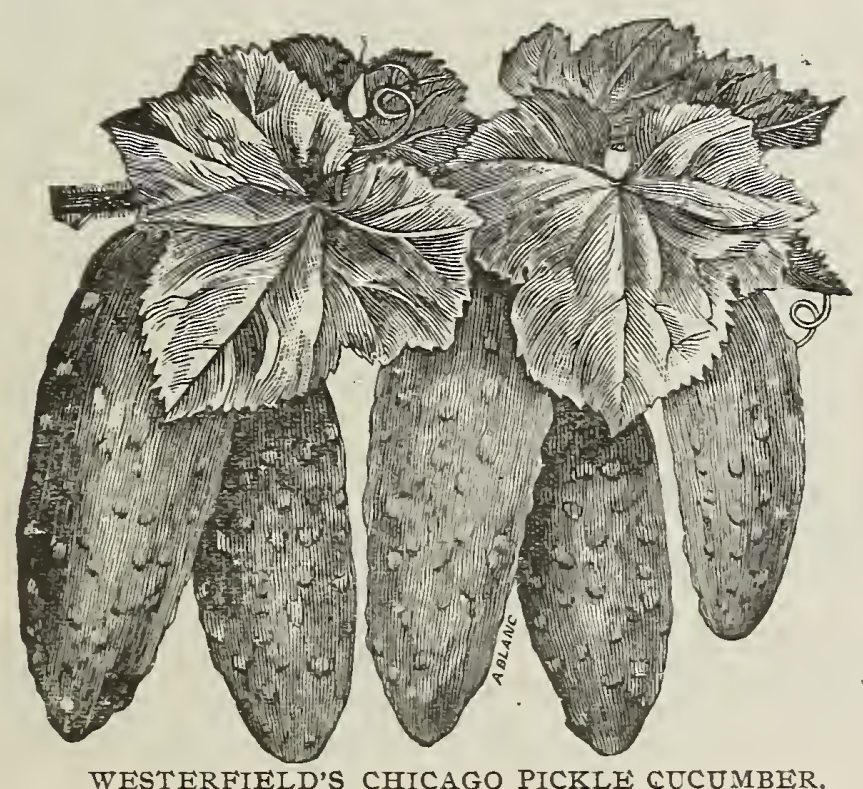

$\$ 0$ Per 10 por

\$o 20

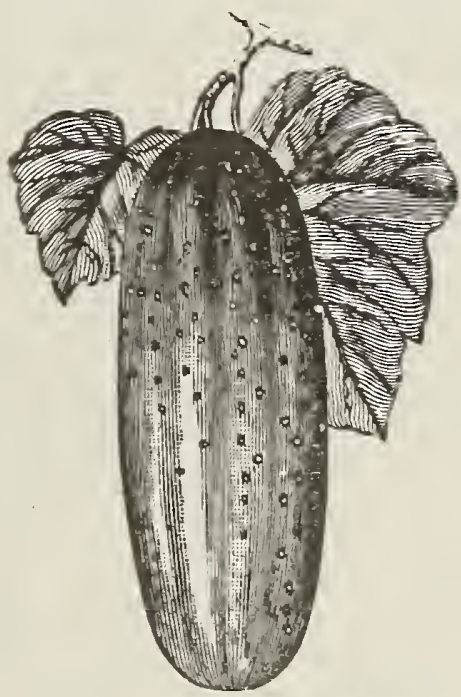

PEERLESS WHITE SPINE.

\section{CUCUMBER}

Davis' Perfect. A beautiful dark green variety, handsome shape and enormous producer; excellent for either forcing or out door culture,

Arlington White Spine. A superior strain for forcing,

Peerless White Spine. Early, handsome, fine cucumber, .

Improved Early White Spine. Med. length, early, tender and crisp,

Extra Long White Spine. Long, slender, excellent for pickles,

Evergreen White Spine. Similar to Ex. Long White Spine, .

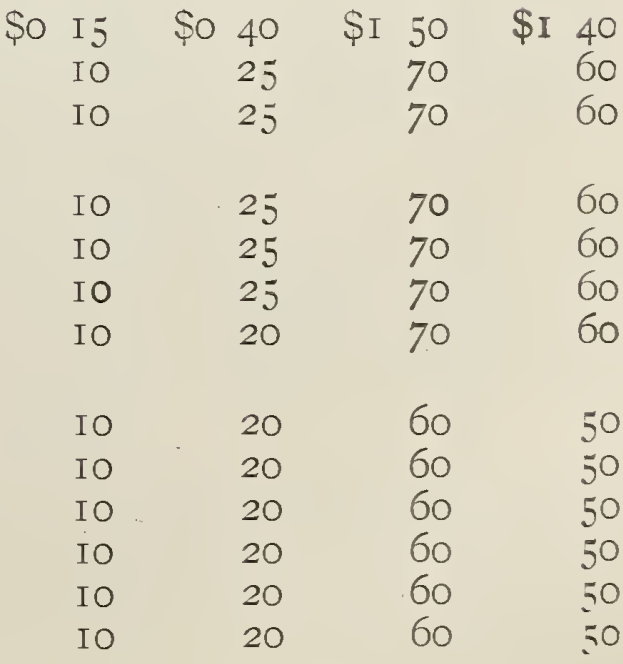

Early Cluster. Medium size, productive, cucumbers clustering about the hill,

Early Short Green. Old familiar variety,

Nichol's Medium Green. Improved short green, . . . IO

Perfected Jersey Pickle. Improved strain, . . . . IO

Green Prolific. Uniform size, dark green, nice for early pickles,

Boston Pickling. A great favorite in Boston market, 


\section{CUCUMBER-Continued.}

Extra Early Russian. Small, extra early variety,

Per oz. \$o 10

Per $1 / 4 \mathrm{lb}$ \$o 20

Per $1 b$. \$o 70

$51 \mathrm{bs}$. or more Per $1 \mathrm{~b}$.

Cool and Crisp. Med. length, very dark green, crisp and tender,

Westerfield's Chicago Pickle. Same class as Green Prolific, . Improved Long Green. Extra long, fine quality, for pickles, . Gherkin or Burr. Small prickly sort, used for small pickles, .
IO

IO

IO

IO

\section{5}

20

20

30

\section{$80^{\circ}$}

60

70

I $\mathrm{OO}$

\section{DANDELION.}

Improved French Large-Cut-Leaved. Excellent for greens,

\section{EGG PLANT.}

Early Round Purple. Small, early variety, • • . . 25

New York Improved Purple. Old standard, . . . . 30

Improved Spineless. Improvement on the above, no spines, . 35

Black Beauty. Earlier than N. Y. Imp., fine quality, . . 35

\begin{tabular}{|c|c|c|}
\hline 80 & 300 & \\
\hline I IO & 375 & \\
\hline I 25 & 400 & \\
\hline I 25 & 400 & \\
\hline
\end{tabular}

\section{ENDIVE.}

Moss Curled. Very fine curled,

Green Curled. Hardy variety for fall or winter, $\cdot$. $^{\prime} \cdot$. IO

White Curled. Very attractive variety, . . . • • IO

Broad-Leaved Batavian. Large head of broad, thick leaves, . Io

\section{HERBS.}

Caraway. Grown for the seeds used in pastry, etc., . . . . 5

Coriander. Seeds are used in confectionery, . . . . 5

Dill. Leaves used for flavoring, . . . . . . 5

Fennel. Leaves used in sauces and for garnishing, . . . 5

Horehound. Used in manufacturing cough medicine, . . I5

Lavender. Sometimes used in making perfumery,. . . . I5

Sweet Marjoram. Leaves are used for flavoring and other culinary purposes, . . . . . . . . . 10

Sage. Used extensively for seasoning and dressing, . . I0

Summer Savory. Useful in culinary purposes, . . . Io

25

90

90

90

70

50

60

90

Thyme. Leaves used for seasoning, .

\section{KALE, or BORECOLE.}

Dwarf Curled Scotch. Hardy, bright green, tender and fine flavor,

Green Curled Scotch. Grows taller than the above,. . .

Dwarf Germans. A great favorite with Germans for greens,

Siberian Curled. Very hardy, dwarf greyish green leaves,

\section{KOHL RABI.}

Early White Vienna. Early and good flavor. Commonly used in this country, . . . . . . . . .

Early Purple Vienna. Similar to the above only in color,

\section{LEEK.}

American Flag. Large, hardy and productive, 


\section{LETTUCE.}

Early White Seeded Tennis Ball or Boston Market. Early cabbage heading variety; medium size, green leaved. A good variety for forcing,

Early Black Seeded Tennis Ball. Improved strain, black seed, Early Curled Silesia. Early, loose head, tender when young, Early Curled White Seeded Simpson. Old popular variety, . Early Curled Black Seeded Simpson. Large, loose head, Market Gardener's Private Stock. Improved Salamander, . Deacon or San Francisco Market. Large, solid head, summer variety,

Henderson's New York Head. Solid head, dark green, .
Early Prize Head. Large, loose head, tinged with brown; excellent,

Big Boston. Excellent for forcing or field culture, large solid green heads,

Grand Rapids (black seed). Great for early forcing,

Improved Hanson. Old and staid head variety, .

Black Seeded Satisfaction. Resembles Salamander,

Salamander. One of the best summer varieties for standing heat, compact tender head, green crumple leaved,

Philadelphia Butter. Early cabbage variety,

Trianon Cos or Celery Lettuce. Leaves when bleached are stiff. like celery,

Per oz

Per $1 / 4 \mathrm{lb}$

5 lbs.

or more

\$o IO

IO

IO

IO

IO

IO

IO

IO

IO

IO

IO

IO

IO

IO

IO

IO \$o 20

20

20

20

20

25

25

25

20

25

25

25

25

25

20

25 \$o 70

$$
70
$$

$$
70
$$

60

70

80

80

80

70

80

90

80

80

80

70

80

\section{OKRA.}

Dwarf White Velvet. Smooth white velvety pods, .

Improved Dwarf Green. Plants dwarf, good size green pods, Long Green Pod. Long slender green pods,

\section{5}

5

5
45

40

45
60

70

\$o 60

60

60

50

60

70

70

70

70

80

70

70

70

60

40

35

40

\section{WATERMELON.}

Vick's Early. A good small melon, skin varies in color, .

Cole's Early. Oblong, striped skin, flesh rich red, fine quality,

Phinney's Early. Fair size, extra early, .

Peerless or Icecream, oblong, white seeded, sweet, . . .

Kleckley Sweet. A good medium early melon, . . . 5 


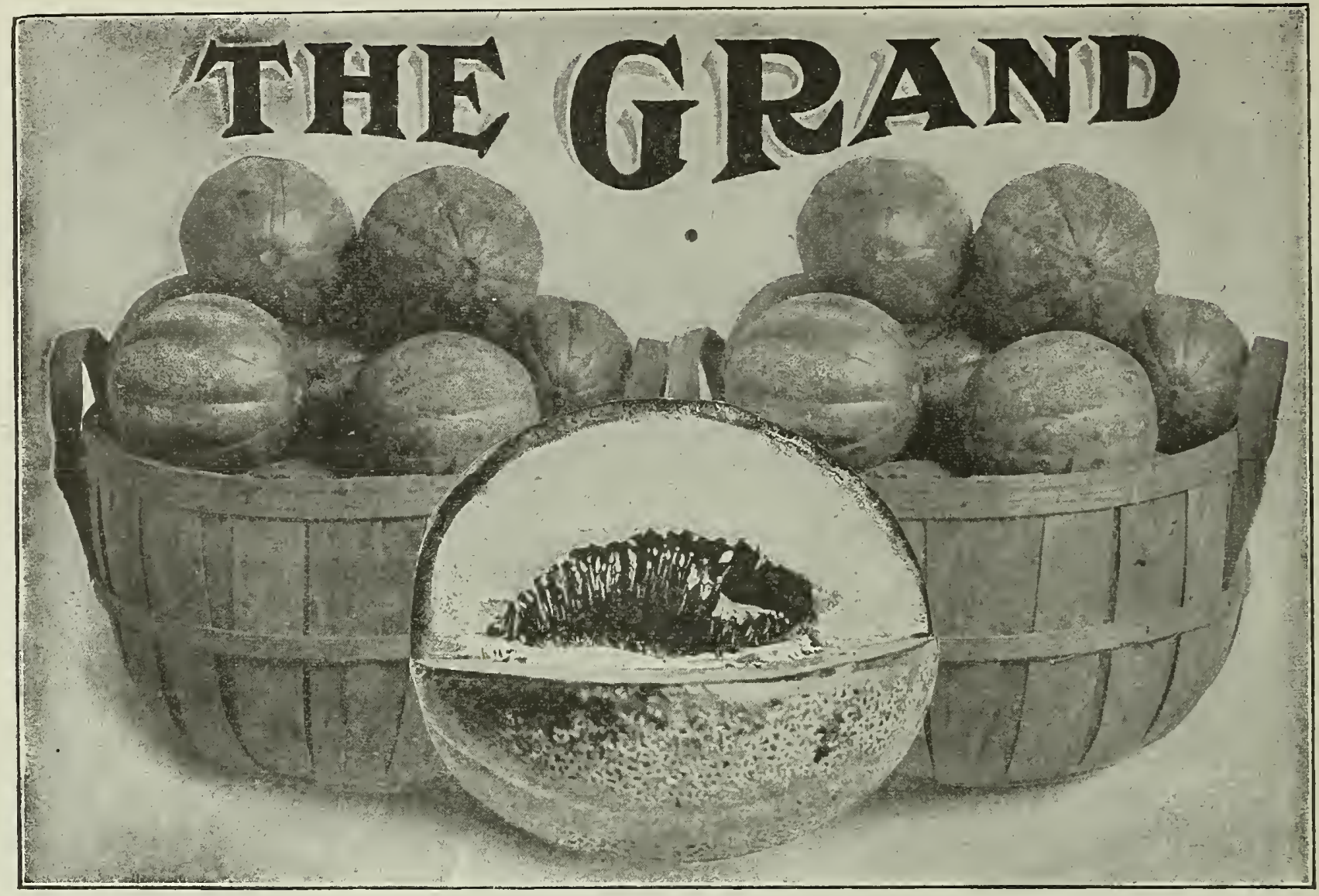

\section{MUSKMELON.}

The Grand. A melon that deserves to be planted in every garden. Good size, green skin well netted, flesh salmon color, very thick and superior. quality,

Paul Rose or Petoskey. Slightly oval, fine netted, heavy ribbed, yellow flesh and very sweet,

Extra Early Jenny Lind. Extra early; small, green flesh, .

Miller's Cream or Osage. Globe shape, dark green skin; flesh salmon color,

Early Hackensack. Week earlier than late Hackensack, .

Montreal Green Nutmeg. Large, green flesh, round with flattened ends,

Hackensack or Turk's Cap. Large, round, green flesh, deeply ribbed,

Improved Christiana or Boston Pet. Extra early, med. size, green skin, rich yellow flesh,

Long Island Beauty. Improved Hackensack, . P
Prolific Green Nutmeg. More prolific than Green Nutmeg,

Rocky Ford. Oblong, fair size and finely netted, sweet, green flesh; great shipper,

Emerald Gem. One of the best melons that grows, salmon color, very sweet, .

Jersey Belle. Improved läge Jenny Lind,

\section{PARSLEY.}

Emerald or Extra Dwarf Curled. Handsome, green curled,

Taber's Exquisite Dwarf, Dark Green Curled. A fine variety,

Extra Triple Curled. More curled than any other, .

Double Curled. Old standard,

Champion Moss Curled. Improvement on Double Curled.
5 lbs.
or more

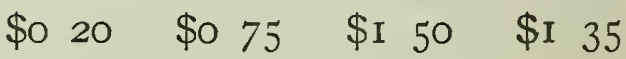

IO $30 \quad$ I $00 \quad 90$

IO

25

75

90
65

IO $\quad 30 \quad$ I $00 \quad 90$

IO 30 I $00 \quad 90$

IO 35 I 25 I ${ }^{*}$ IO

IO $\quad 30 \quad$ I $00 \quad 90$

IO $\quad 30 \quad$ I $00 \quad 90$

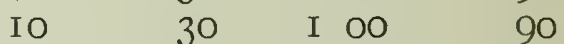

IO 30 I $00 \quad 90$

IO $\quad 25 \quad 75$

I 5

IO

35

25

I 25

I $\mathrm{OO}$

I IO

90

5 lbs. or more Pcroz. Per $1 / 41 b$. Per $1 b$. Per $1 b$.

$5 \quad$ I5 $50 \quad 45$

IO $\quad 20 \quad 60 \quad 55$

IO $20 \quad 60 \quad 55$

$5 \quad I 5 \quad 50 \quad 45$

5 I $5 \quad 50 \quad 45$ 


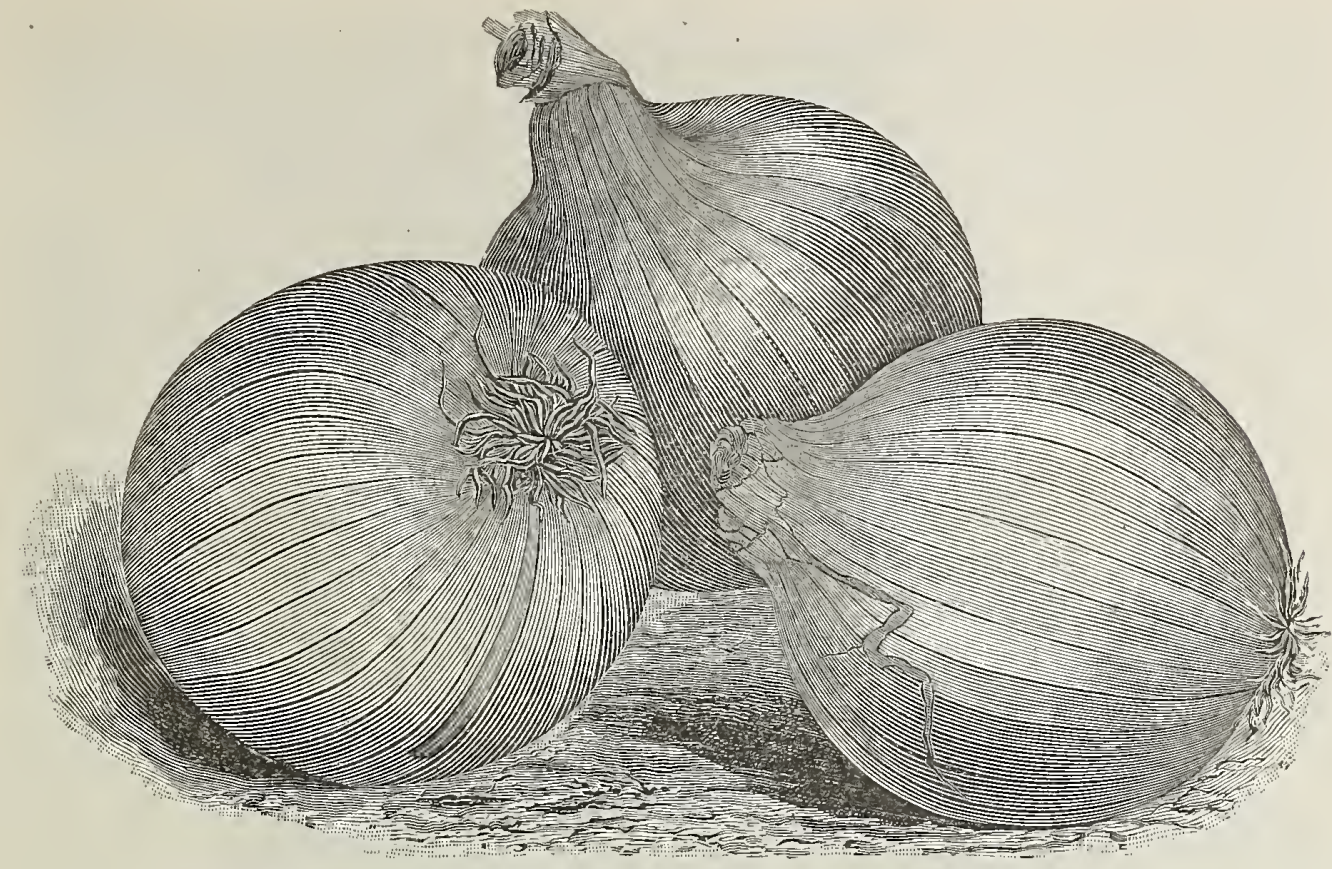

Perfect Yellow Globo Danver's Onion.

\section{ONION.}

Wethersfield (sometimes called Onion town) is noted for its fine quality of onion seed. We are old onion seed growers and are very careful to have our stocks pure and of the best quality, and we sell large quantities every year to a very critical trade.

Yellow Danvers. Round, bright yellow, .

Yellow Globe Danvers. A globe shaped onion, little flattened at bottom,

Perfect Yellow Globe Danvers. A very fine strain, . .

Michigan Yellow Globe. Globe shaped, good onion for heavy land,

Ohio Yellow Globe. Very popular in Ohio markets,

Southport Yellow Globe. True globe shaped,

Yellow Dutch or Strasburg. Flat onion, sowed extensively for sets,

Prize Taker. Very large, handsome yellow onion,

Early Red Flat. About ten days earlier than Red W'f'd,

Large Red Wethersfield. The old reliable,

Southport Red Globe. Great for Eastern markets, .

Silver Skin or White Portugal. Flattish round onion, good quality,

Southport White Globe. Best white onion for market,

Early White Barletta. Extra early, small pickling onion,

Early White Queen. Quite similar to Barletta,

\begin{tabular}{|c|c|c|c|c|c|}
\hline Per oz. & Per $1 / 41 \mathrm{~b}$. & & lb. & & $\begin{array}{l}\text { 1b. } \\
\text { nore } \\
\text { lb. }\end{array}$ \\
\hline \$o I 5 & \$o 40 & $\$ I$ & 30 & \$I & 20 \\
\hline I 5 & 45 & I & 40 & I & 25 \\
\hline I 5 & 50 & I & 50 & I & 35 \\
\hline I 5 & 45 & I & 40 & I & 25 \\
\hline I 5 & 45 & I & 40 & I & 25 \\
\hline 20 & 50 & I & 50 & I & 35 \\
\hline I 5 & 40 & I & 50 & I & 40 \\
\hline I 5 & 40 & I & 50 & I & 40 \\
\hline I 5 & 50 & I & 60 & I & 50 \\
\hline I 5 & 50 & I & 60 & I & 50 \\
\hline I 5 & $5^{\circ}$ & I & 65 & I & 50 \\
\hline 20 & 65 & 2 & OO & I & 80 \\
\hline 25 & 75 & 2 & 25 & 2 & ০o \\
\hline I 5 & 40 & I & 40 & I & 30 \\
\hline I 5 & 40 & & 40 & I & 30 \\
\hline
\end{tabular}

\section{ONION SETS.}

Please remember that we give $35 \mathrm{lbs}$. to the bushel. Most dealers only give $32 \mathrm{lbs}$.

Per quart. 4 quarts.

\$o I 5 \$o 45

I 5

Yellow Onion Sets (Bush. 35 lbs.)

White Onion Sets (Bush. 35 lbs.)
45

55
Per pk.

\$o 75

Per bu.

$\$ 275$

275

95
5 bus. or more

$\$ 260$

260

340 


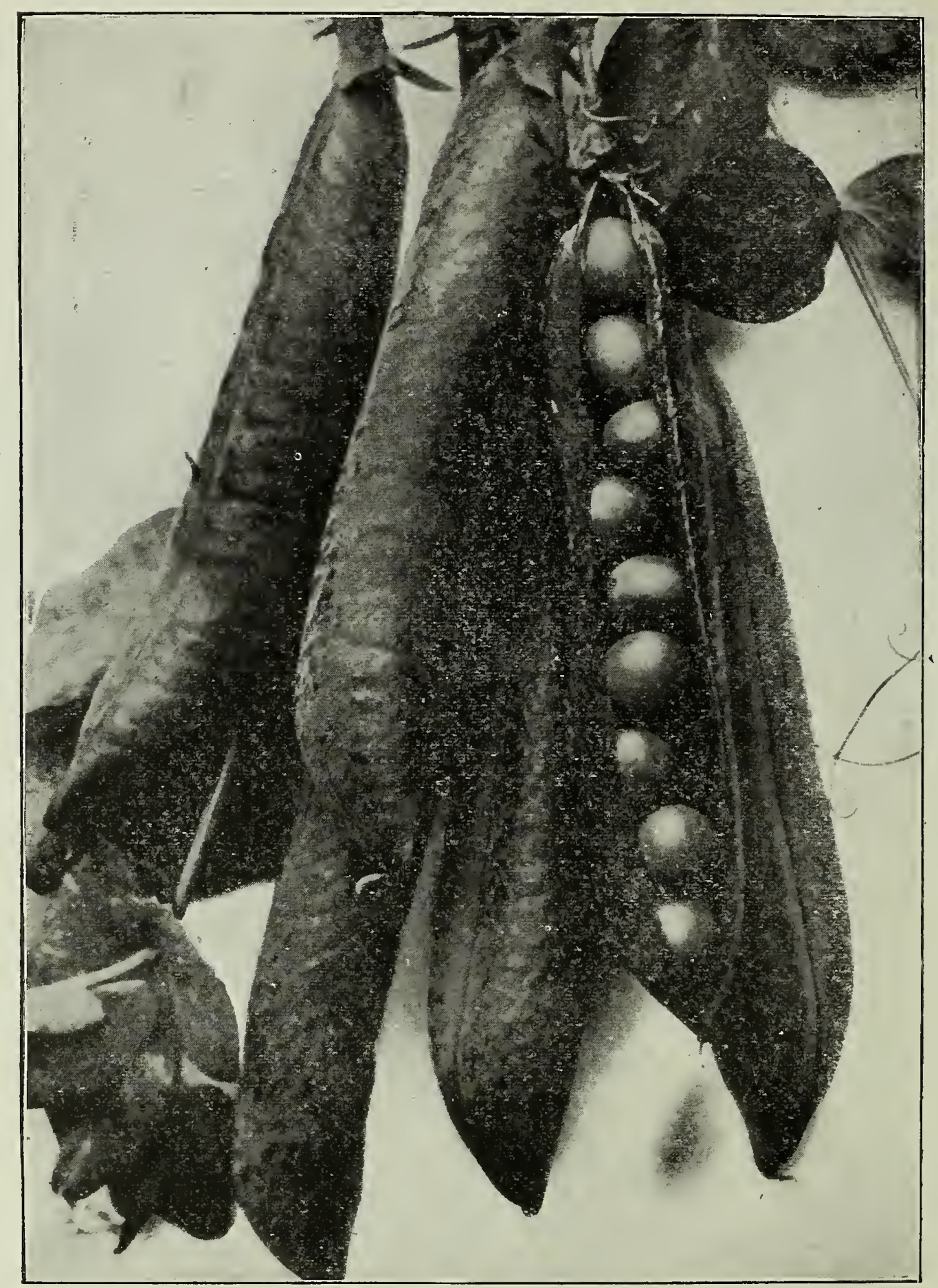

THOMAS IAATTON PEAS.

\section{PEAS.-First Early Varieties.}

Maud S. Superior strain of the extra early variety, $21 / 2$ feet, . East Hartford Extra Early. Very popular with gardeners Per quart, 4 quarts. Per peck. Per bu. around Hartford, $2^{\mathrm{T} / 2}$ feet, .

Philadelphia Extra Early. The old and tried sort, $2 \frac{1}{2}$ feet, First and Best. One of the earliest, $21 / 2$ feet

Alaska or Laxton's Earliest of All. Good market variety, $2 \frac{1}{2}$ feet,

* Gradus or Prosperity. Earliest large podded variety, extra fine; our strain is of true type, $2 \frac{1}{2}$ to 3 feet,

*Thomas Laxton. Large handsome pods, first class quality, 3 feet,

*Extra Early Premium Gem. Imp'd Little Gem, is inches,

\$o 20 \$o 60 \$I IO $\$ 400$

$20 \quad 60$ I $10 \quad 400$

I $5 \quad 50 \quad 90 \quad 350$

I $530 \quad 95 \quad 360$

$20 \quad 70 \quad$ I $20 \quad 4.50$

$\begin{array}{llllll}25 & 85 & \text { I } & 50 & 5 & 50\end{array}$

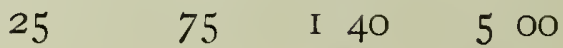

$20 \quad 70 \quad$ I $20 \quad 480$


First Early Varieties.-Continued.

* McLean's Little Gem. A very popular garden pea, I8 inches,

*American Wonder. Medium sized pod, flavor of the best, 9 inches,

*Nott's Excelsior. Improved American Wonder, better yielder, I 5 inches,

*Sutton's Excelsior. This is one of the best peas in cultivation, similar in growth to Nott's Excelsior, but excelling same in bearing; much larger pods filled with large tender peas of delicious flavor, I 5 inches,

\section{Second Early Varieties.}

*Bliss' Abundance. Well filled pods, prolific, fine flavor, 20 in.,

*McLean's Advancer. Good sized, well filled pods, excellent quality, 2 feet,

*Shropshire Hero. Much improved Yorkshire Hero, better quality, $2 \mathrm{~T} / 2$ feet, .

*Horsford Market Garden. Similar to Abundance, 2 feet, .

*Heroine. Pods long, filled with fine flavored peas, very prolific, 2 feet,

*Juno. Robust and vigorous in growth bearing straight pods of medium size, and well filled with fine flavored peas, $2 \mathrm{ft}$.,

\section{General Crop Varieties.}

*Sharp's Queen. Large, handsome pods; delicious peas, $2^{1} / 2 \mathrm{ft}$. *Improved Stratagem. Valuable market garden sort, 2 feet,

*Bliss' Everbearing. Vigorous branching vines, good sized pods, $z$ feet, .

*Dwarf Champion or Duke of Albany. Fine variety, $2 \mathrm{~T} / 2 \mathrm{ft}$.

*Carter's Telephone. Vine and leaves large and coarse, long straight pods; peas large, tender and sweet. Popular with many growers, but liable to sport and it is very difficult to grow a pure stock, $3^{1 / 2}$ feet, .

*Allan's Improved Telephone. A much improved type of Carter's Telephone, longer and deeper green pods, $3 \frac{1}{2}$ feet,

*Sutton's Defiance. Large pods full of delicious flavored peas, 20 inches,

Admiral Dewey. Remarkably healthy, vigorous and very productive. Pods of large size, straight, rounded at point, dark green color and filled with large, rich flavored peas, 4 feet,

*Champion of England. Everybody knows this variety, 5 feet,

Black Eyed Marrowfat. More for stock feeding,

Canada Field. Excellent to sow with oats for feed, *Wrinkled Varieties.

\section{PARSNIP.}

Improved Guernsey. Med. long, superior quality, .

Hollow Crown Improved. One of the best for general use, Large Smooth Sugar. Quite like Hollow Crown,

\section{PEPPER.}

Neapolitan. A large, early, bright red Pepper of mild flavor. Shape similar to Sweet Mountain. Heavy producer,

Large Bell or Bull Nose. A thick pepper, excellent for stuffing,

Sweet Mountain. Little longer shaped than Bull Nose,

Ruby King. Very large and mild flavor,

Ruby Giant. A cross between Ruby King and Chinese Giant, resembling Ruby King but much larger fruit and more prolific,
Per quart.

$\$ 020$

4 quarts.

Per peck

Per bu.

25

25

70

I 35

475

25

70

I 35

475

25

75

I 40

5 oo

20

60

I IO

400

20

60

I IO

400

20

60

I 05

400

95

375

20

20

60

I IO

400

60

I IO

400

20

25

20

20

\section{0}

$$
75
$$

I IO

400

\section{0}

60

I IO

I IO

400

400

\section{0}

20

20

\section{0}

I 25

475

75 I 40

500

75

I 40

5 oo

\section{0}

I 5

IO

IO

\section{5}




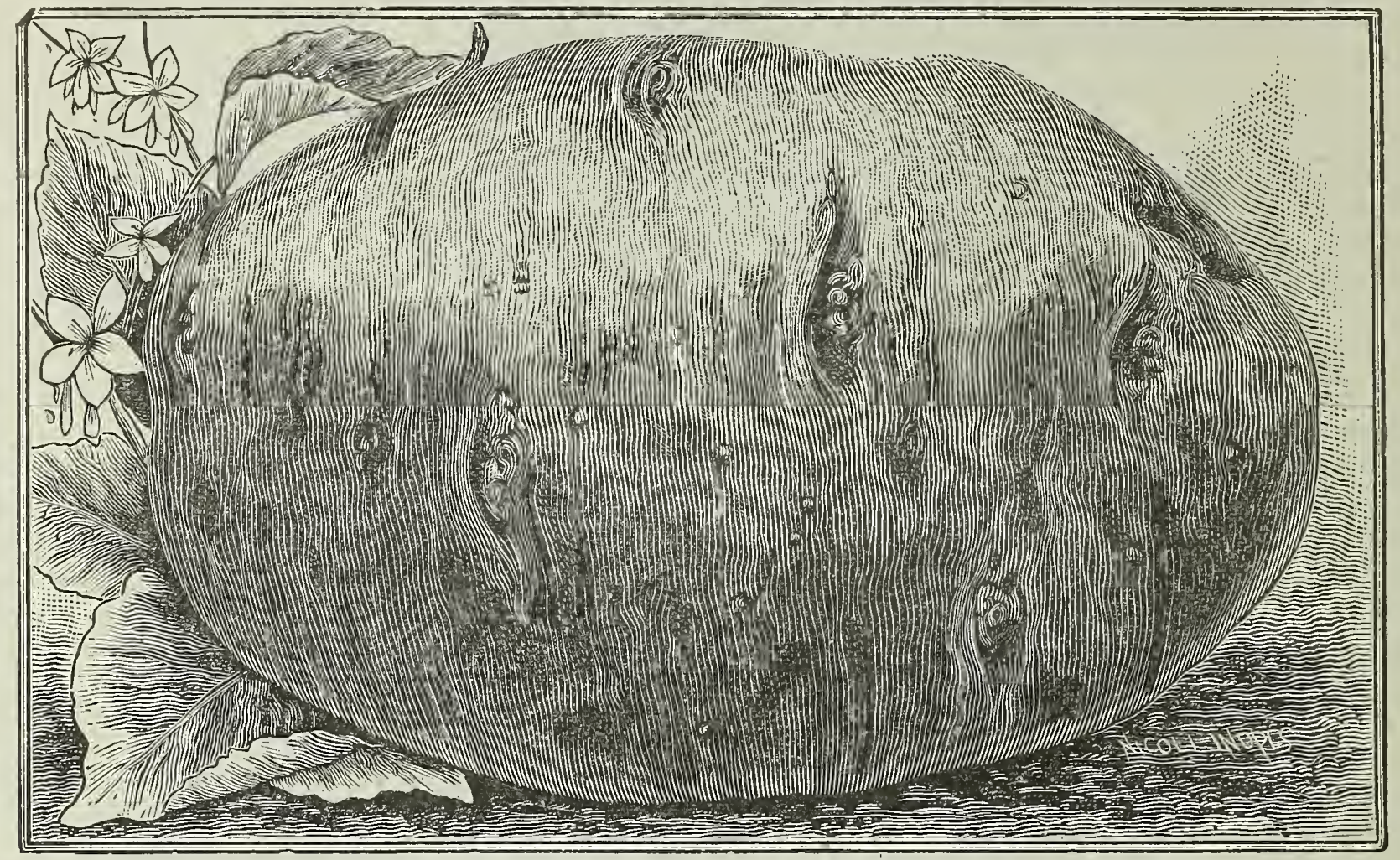

\section{MAINE GROWN SEED POTATOES.}

There is probably no crop grown that is benefited more by change of seed than the potato. This has been demonstrated extensively by ourselves and others in this vicinity and proven that the Northern Grown Seed produces much better results both in yield and quality of the potatoes, and growers realize this fact and are planting more every year of this Maine grown stock in preference to their native seed. We have thousands of bushels of these potatoes contracted for and stored in frost-proof cellars in Maine to be shipped to us in the spring and expect they will reach us about April Ioth. And can be reshipped to our customers direct from the cars as soon as they arrive.

The prices we quote are what seems to us fair prices at the time this catalogue is printed but are subject to market fluctuations.

Junior Pride or White Bliss. Early, round, uniform in shape; medium sized vine, which dies down early in the season and does not rust or blight,

Irish Cobbler. Early, cream-white color, nearly round; fair quality; vigorous grower,

Early Harvest. Handsome oblong white potato; great yielder,

Early Rose. An old well-known variety, . . . .

Early Beauty of Hebron. A great favorite with most planters,

Carman No. I. Heavy yielder of large handsome white potatoes; fine quality,

Carman No. 3. Longer in shape than No. I, excellent quality,

Golden Prolific. Resembles the Green Mountain in color and 


\section{SEED POTATOES. - Continued.}

\section{PUMPKIN.}

Winter Luxury. An excellent small pie pumpkin, round, golden russet color, finely netted, flesh yellow, sweet and tender, good keeper,

Small Yellow Sugar. One of the best pie pumpkins, . .

Large Cheese. Round, flattish pumpkin, ribbed, . . . 5

Mammoth Tours. Very large, green color,

Mammoth Potiron or King of Mammoth. Great pumpkin for

fairs,
Connecticut Field. Old standard, excellent for feeding, .

\begin{tabular}{|c|c|c|c|}
\hline & & $\begin{array}{l}\text { Per bbl. } \\
\text { k } 165 \text { lbs. }\end{array}$ & $\begin{array}{l}5 \text { sack } \\
\text { or more } \\
\text { ter sack. } \\
\text { t. }\end{array}$ \\
\hline & & $\$ 325$ & $\$ 3$ I 5 \\
\hline & & $\begin{array}{ll}3 & 35 \\
3 & 35\end{array}$ & $\begin{array}{ll}3 & 25 \\
3 & 25\end{array}$ \\
\hline Per oz. & Per $1 / 4 \mathrm{lb}$. & Per $1 b$. & $\begin{array}{l}5 \text { lbs. } \\
\text { or more } \\
\text { Per } 1 \mathrm{~b} \text {. }\end{array}$ \\
\hline IO & $\$ 020$ & $\$ 050$ & \$o 45 \\
\hline 5 & I 5 & 35 & 30 \\
\hline 5 & I 5 & 35 & 30 \\
\hline IO & 30 & I 00 & 90 \\
\hline IO & 30 & I $\infty$ & 90 \\
\hline 5 & IO & 20 & 18 \\
\hline
\end{tabular}

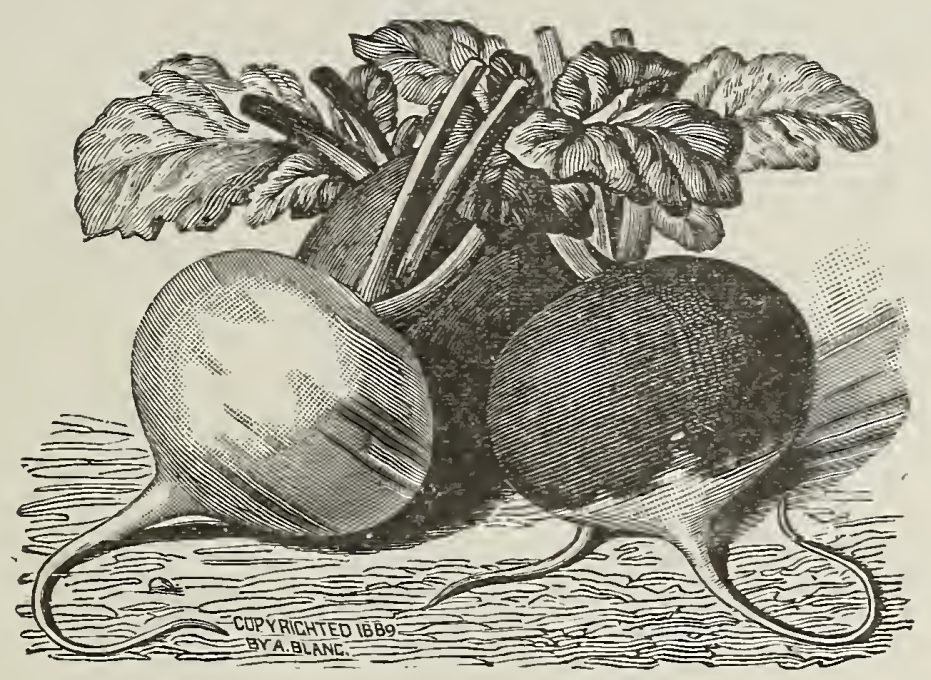

\section{RADISH.}

Carmine Olive-Shaped. A beautiful bright red radish, . . Io

Extra Early Erfurt. One of the earliest turnip radishes, . Io

Rosy Gem. Either for greenhouse or open culture; round

Early Deep Scarlet Turnip. Very deep color; excellent,

Half Long Deep Scarlet. Excellent, of medium length,

Early Red Turnip. A popular garden variety, .

Early Scarlet Turnip. Like the preceding, lighter color

Early Scarlet Turnip, White Tip. Round scarlet radish with white root,

Early French Breakfast. A short radish with white root,

Early White Turnip. An early summer variety, ${ }^{\circ}$ Olive Shaped Scarlet. Shaped like an olive, bright scarlet color,

Early Short Top Long Scarlet. The old standard long radish, 


\section{RADISH.-Continued.}

White Strasburg. A leading summer variety, .

Peroz. Per $1 / 4 \mathrm{lb}$. Per lb.

\$o 05

5

5

Chartier. A long scarlet radish, white root,

Chinese Rose-Winter. Excellent winter variety, .

Long Black Spanish-Winter. Large and hardy, keeping until spring,

Round Black Spanish-Winter. Globe-shaped, fine quality, .

\section{RHUBARB, or Pie Plant.}

Large Victoria. The most popular variety,

IO

30

I $\mathrm{OO}$

90

\section{SUNFLOWER.}

Mammoth Russian. Very large flower, seeds excellent for fowls,

IO

I5

IO

\section{SALSIFY, or Vegetable Oyster.}

Long White. The standard variety, .

Mammoth Sandwich Island. The largest,

Io

Io

$51 \mathrm{bs}$.

or more

\$o 35

35

35

35

35

35

40

.




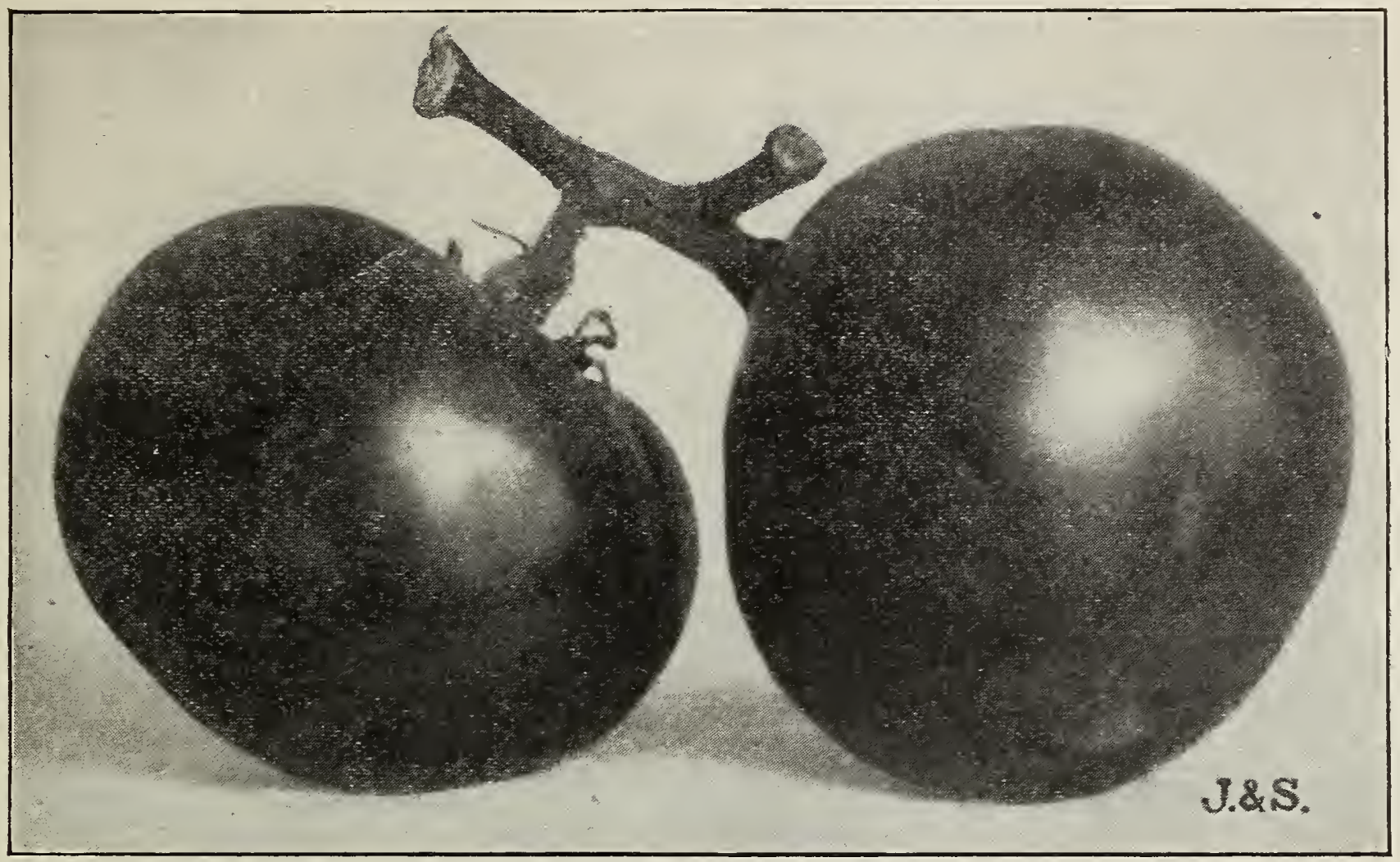

TOMATO.

June Pink. Early pink iomato of good quality,

Chalk's Early Jewel. Best extra early, smooth, red tomato,

Sparks' Earliana. Very early, good size, but inclined to be rough,

Atlantic Prize. A fine, extra early, red variety for general use,

Early Acme. Good family tomato; solid, pinkish color, .

Maul's Imperial. Superior quality, pink color,

Livingston's Pink Globe. A very good all-round Tomato, but if grown on very rich soil is liable- to crack. Pink in color, globe shaped, flesh very meaty, good flavor and great cropper, 20

Per oz So 20

20

20

Livingston's Coreless. One of Livingston's new productions, a large, bright red Tomato, globe shaped, strong grower and big cropper, . . . . . . . .

Livingston's Beauty. Large, thick tomato, light purple, . .

Livingston's Favorite. Bright red and smooth,

Livingston's New Stone. The best all around tomato, bright red,

Livingston's Prefection. A favorite with canners, . .

Livingston's New Dwarf Stone. Short, stocky vine; fine large, smooth, red tomato,

. . . . . $\quad$ I5

Golden Trophy. Like the preceding, only yellow, . . . I5

Golden Queen. Similar to Golden Trophy, . . . . I5

Dwarf Champion. Solid, smooth dwarf, pinkish variety, . 20

Dwarf Aristocrat. Like Dwarf Champion, bright red, . . 20

Table Queen. Purplish red, large and solid, . . . . $\quad$ I5

Pear Shaped Yellow. Small oblong variety, . . . . I5

Yellow Plum. Small, round tomato, . . . . . . . I5

Yellow Cherry. Smaller than plum, . . . . . . I5

Henderson's Ponderosa. Very large, rather coarse grained, . 20

Enormous. The best extremely large tomato, fine quality, .
I 5

15

15

65

Per $1 \mathrm{~b}$ $\$ 250$

250

\section{5}

45

45

45

250

I 60

I- 60

I 75

I 60 


\section{TURNIP.}

Extra Early Milan Purple-Top. The earliest,

Purple Top Flat Strap-Leaved. Well-known variety,

Early White Flat Dutch. Same shape as the preceding, white,

Strap-Leaved White Flat. Flat white turnip, .

Large Red Top Globe. Large white turnip with red top,

Long White Cow Horn. Heavy cropper; excellent for stock,

White Egg. Handsome pure white, med. size; fine market variety,

Pomeranian White Globe. Large, pure white,

Yellow Aberdeen. Very large green top, good for table or stock,

Yellow Stone. Very solid and smooth; excellent for winter, .

Golden Ball. A smallish, smooth, yellow turnip; excellent keeper,

Purple Top Yellow Globe. Large yellow turnip with purple top,

Green Top Yellow Globe. Old standard variety,

\section{RUTA BAGA, or Swedish Turnip.}

Sweet German. Long, white, smooth and tender,

White French or Rock. Improvement on the preceding,

Breadstone or Budlong. The best white variety, •
Am. Improved Purple-Top Yellow. Very hardy and productive,

Skirving's Purple-Top Yellow. Large size, strong growth, Waite's Improved Purple-Top Yellow. An improved type, Long Island Improved Purple-Top Yellow. One of the best, .

\begin{tabular}{|c|c|c|c|}
\hline Per oz. & Per $1 / \mathrm{lb}$. & Per $1 b$. & $\begin{array}{l}5 \text { lbs. } \\
\text { or more } \\
\text { Per } 1 \mathrm{~b} .\end{array}$ \\
\hline \$o 05 . & \$o I5 & $\$ 040$ & \$o 35 \\
\hline 5 & IO & 25 & 22 \\
\hline 5 & IO & 25 & 22 \\
\hline 5 & IO & 25 & 22 \\
\hline 5 & Io & 25 & 22 \\
\hline 5 & I 5 & 30 & 25 \\
\hline 5 & I 5 & 30 & 25 \\
\hline 5 & 10 & 25 & 22 \\
\hline 5 & IO & 25 & 22 \\
\hline 5 & IO & 25 & 22 \\
\hline 5 & IO & 25 & 22 \\
\hline 5 & 10 & 25 & 22 \\
\hline 5 & IO & 25 & 22 \\
\hline
\end{tabular}

$\begin{array}{llll}5 & \text { 10 } & 25 & 22 \\ 5 & \text { 10 } & 25 & 22 \\ 5 & \text { 10 } & 25 & 22\end{array}$

$5 \quad$ IO $\quad 25 \quad 22$

5 IO $25 \quad 22$

5 IO $25 \quad 22$

$5 \quad 10 \quad 25 \quad 22$

We furnish seed to Granges, Farmers' Clubs, Public and Private Institutions and thousands of individuals.

Let us supply your wants in this line. 


\section{GRASS SEED.}

We are Headquarters for High Grade Grass Seed. Don't buy a Poor Grade. The Best is far the Cheapest in the end.

Many a farmer makes a mistake by buying a cheap grade of seed thinking he is saving money by so doing, but think of the result. Suppose it does cost a few cents more an acre to seed down your land with good seed, what is that compared to sowing a low grade of seed, filling your land full of weeds and being disappointed in the hay crop. You can buy a cheap grade of seed in the market if you wish it, but we don't care to handle cheap grades, they are very unsatisfactory.

We sell tons and tons of high grade seed, and our trade is rapidly increasing. This is the seed you should buy. Prices subject to market fluctuation.

Fancy Lawn Grass Mixture,

Red Top. Sown alone or with Timothy makes excellent hay, Timothy or Herds Grass. Makes fine horse hay (bush. 45 lbs.), Orchard Grass. Good to sow with other grass seed for pasture and shady places, .

Kentucky Blue Grass. Valuable for pasture when mixed with other varieties,

English Rye Grass. A permanent nutritious meadow grass, .

Meadow Fox Tail Grass. Earlier than timothy, which it resembles,

Tall Meadow Oat Grass. Early, luxuriant growth, excellent for pasturing or hay,
Per ib.

\$o 20

19

08

14

20

I2

28

2 I

\section{CLOVER SEED.}

Alsike. Excellent for permanent pasturage, very hardy, good for wet or dry soil (Bush. 60 lbs.),

Alfalfa or Lucerne. When well rooted is very hardy, three crops in one season, fine cow feed (Bush. 60 lbs.), .

White Dutch. Good for pastures, when sown with red clover,

Medium Red. This is the common hay clover so extensively used (Bush. 6o lbs.),

Mammoth Red or Pea Vine. Excellent to plow under for green manure (Bush. 60 lbs.),

Crimson or Scarlet Italian. Excellent for bees also to plow under (Bush. 60 lbs.),

\section{MILLET.}

German or Golden. (Bush. 50 lbs.), slower grower and some taller than Hungarian, .

Hungarian Grass or Millet. (Bush. 48.1bs.), extensively sown to help out late feed and hay crop, . . . . .

Japanese or Barnyard Millet. (Bush. 32 lbs.), a great forage plant, very heavy cropper, .
20

I9

$18 \mathrm{I} / 2$

I8

20

20

I9

$18 \mathrm{I} / 2$

18

I9

18

I7

IT

I6

I 5

I4

I7

I6

I5

I4

I I

IO

$\infty 1 / 2$

09 


\section{Field and Ensilage Corn.}

Field and Ensilage Corn is generally a very important crop with the farmer and it is well for him to take special pains to plant good. stock. Most of our Field and Ensilage Corn is grown for us in the Nebraska corn belt, where it matures to perfection, and is of strong vitality, and also a change from corn that is grown here in the East year after year.

\section{THOROUGHBRED LEAMING}

A leader of the Yellow Dent varieties and is extensively grown for ensilage purposes. It is a strain of the Improved Leaming, bred up to its highest efficiency, ripening about the same time as the old style, kernels and ears more uniform, better filled out arid of much purer type. It has a good sized stalk with abundance of leaves and is a heavy yielder of large, handsome ears, making it a valuable variety for general purposes.

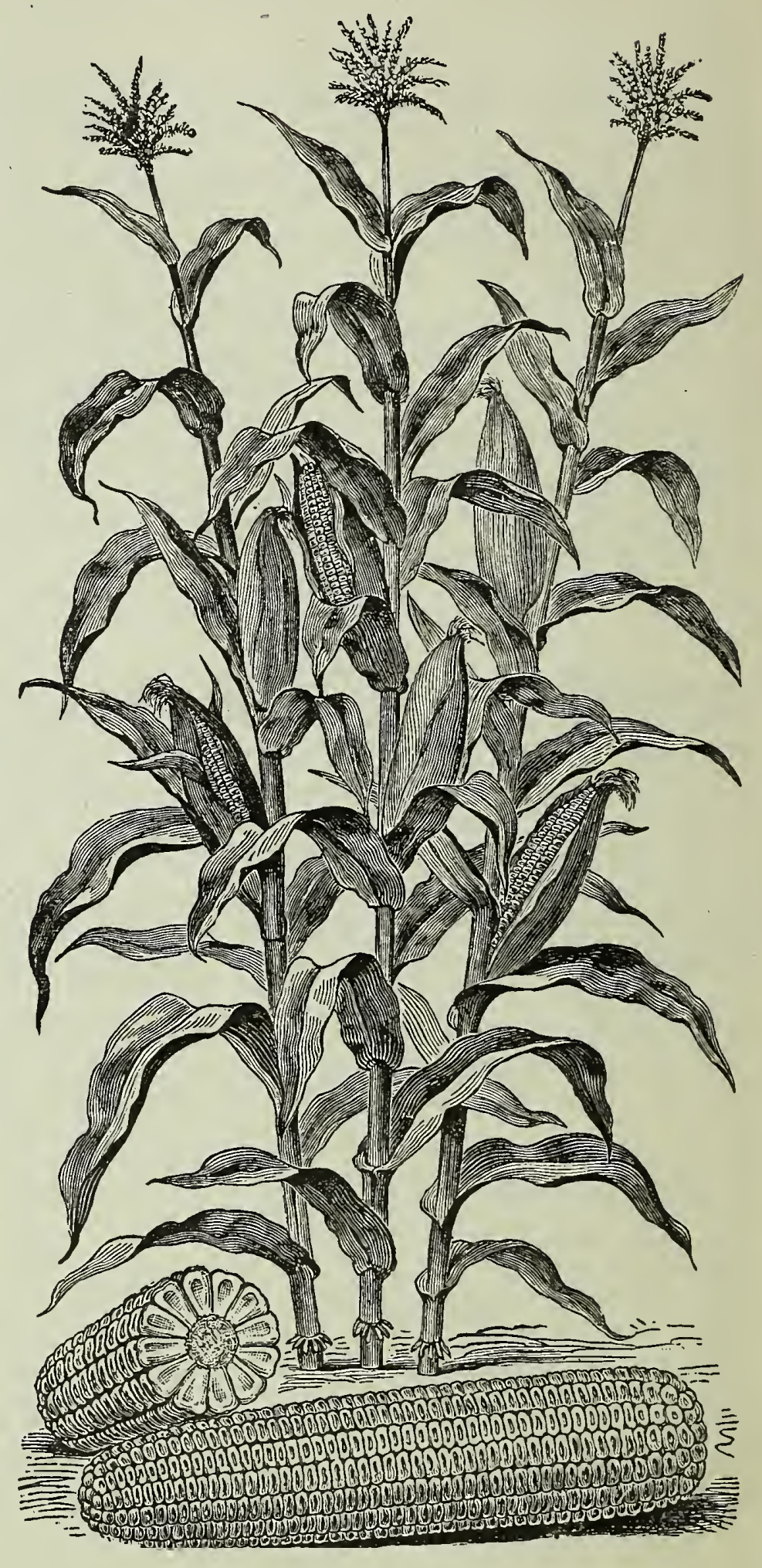

Per4quarts. Per peck Per bu. $\begin{aligned} & 2 \text { bus. } \\ & \text { or more } \\ & \text { Per bu, }\end{aligned}$

Ninety-Day Yellow (true stock); probably the earliest field corn in cultivation; bright yellow flint, small cob and very prolific. A bushel of ears generally shelling about 24 quarts of shelled corn, .

Early Canada Yellow. Medium size flint corn, extensively grown in New England,

$\begin{array}{llllllllll}\$ 0 & 25 & \$ 0 & 40 & \$ \mathrm{I} & 40 & \$ \mathrm{I} & 25\end{array}$

$25 \quad 40 \quad$ I $40 \quad$ I 25 
FIELD AND ENSILAGE CORN.-continued.

Pride of the North. Early maturing Dent variety, good for ear or ensilage,

Reed's Improved Yellow Dent. A very choice strain of Yellow Dent,

Early Leaming. Ears large, deep kernel, excellent for ear corn or ensilage,

Thoroughbred Leaming. Improved type; see illus., page 22 ,

Red Cob Ensilage. A late white corn, red cob, used extensively for ensilage,

Sweet Corn for Fodder,
Per 4 quarts. So 25

25

25

25

25

35
Per peck.

Per bu.

2 bus.

or more

Per bu.

\section{SEED OATS.}

Swedish Select. A new oat of Swedish origin brought to this country by the U. S. Department of Agriculture and has proved to be one of the heaviest grain, thinest hull, stiffest straw and heaviest yielding varieties known,

Large Dutch. A very heavy, full meated oat quite similar to the Swedish Select,

Lincoln. Early, rust proof and hardy, straw stiff and strong, American Banner. A thrifty variety well known in New England,

White Queen. An excellent white variety, hardy and prolific,

Silver Mine. Large white oat and very heavy yielder, . .

Common Seed Oats,
\$I 25

I 40

I 25

I 40

I 35

I 75

$\begin{array}{llllll}25 & 40 & \text { I } & 25 & \text { I } & \text { IO } \\ 5 & 40 & \text { I } & 25 & \text { I } & \text { IO } \\ 20 & 35 & \text { I } & 00 & & 90 \\ & & & & & \\ 20 & 35 & \text { I } & 00 & & 90 \\ 20 & 35 & \text { I } & 00 & & 90 \\ 20 & 35 & \text { I } & 00 & & 90 \\ \text { I5 } & 25 & & 90 & & 80\end{array}$

\section{MISCELLANEOUS.}

Russian Sand or Hairy Vetches. (Bush. 6o lbs.), sown alone Per 4 quarts, Per peck. Per bu. or with rye and clover, makes fine winter covering; excellent to plow under to enrich the soil, . ${ }^{\circ}$. also for cattle and hogs,

.$\$ 070$

60

Whip-Poor-Will Cow Peas. (Bush. 60 lbs.), early-maturing variety; vigorous, upright growth, .

Clay Cow Peas. (Bush. 6o lbs.), well adapted for the north; very productive, .

Mixed Cow Peas. (Bush. 6o lbs.), different varieties mixed, great for soil enriching,

Spring Rye. (Bush. 56 lbs.), excellent to sow for catch crop where winter crop has failed,

Winter White Iiye. (Bush. 56 lbs.), a variety for fall sowing to stand over winter,

Barley. (Buslı 48 lbs.), sown extensively in New England for fodder,
55

$\$ 450$

I IO

425

400

90

$325^{\circ}$

300

$90 \quad 325$

300

$80 \quad 300$

280

50

I 75

I 60

30

I IO

I 00

30

A well kept flower garden is an ornament to a place, and flowers are a pleasure and a blessing to a home. On the following pages we list a line of choice flower seeds imported direct from one of the best flower seed growers in Europe. 

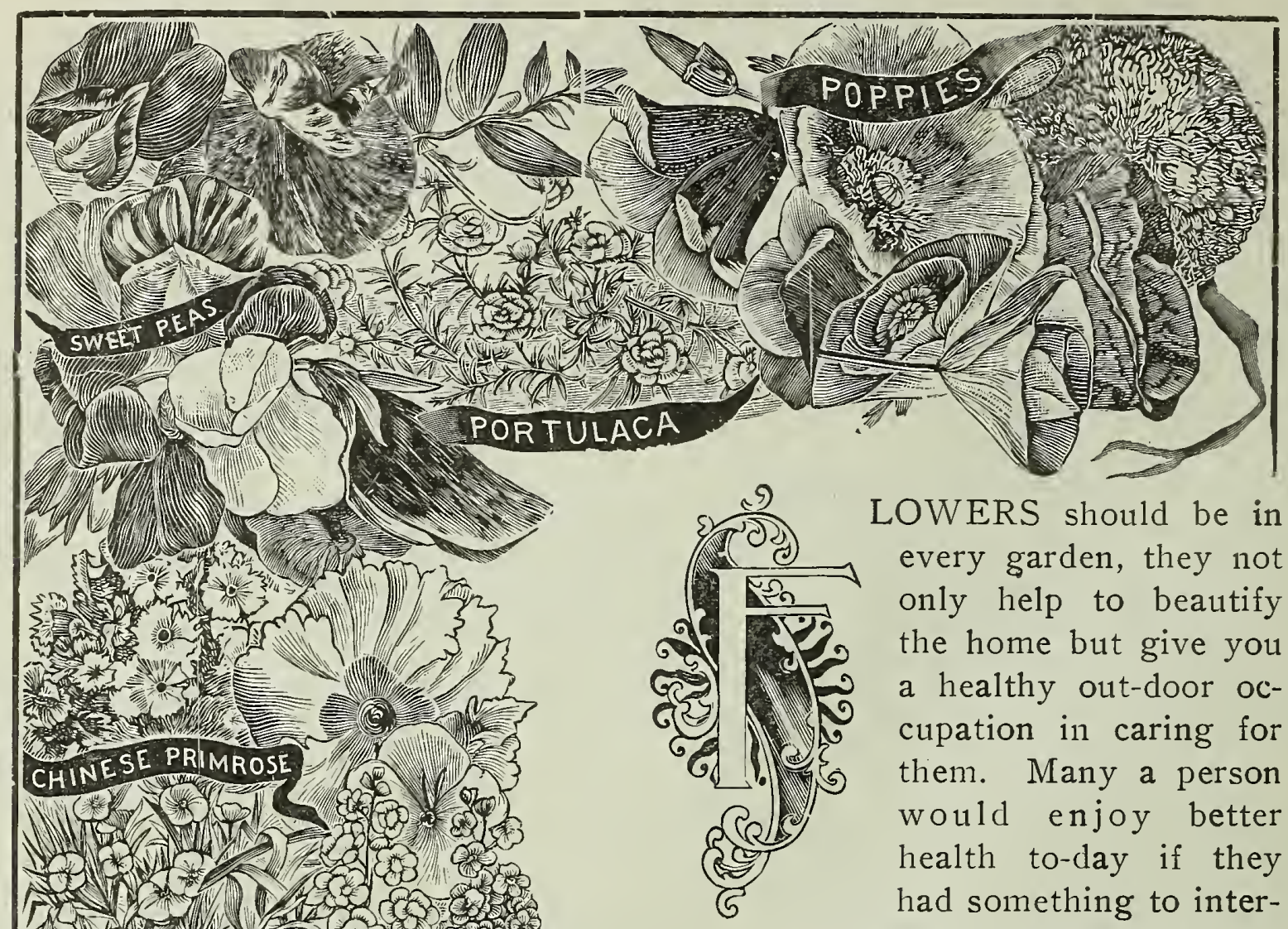

LOWERS should be in every garden, they not only help to beautify the home but give you a healthy out-door occupation in caring for them. Many a person would enjoy better health to-day if they had something to interest and bring them out more into the sunshine and pure air, and what is better for this than a nice flower garden, for any one that loves flowers. Let the children have a little flower garden and teach them the value and care of flowers, they will take more interest in them than you may think. Try a few of the old fashion varieties that your mother and grandmother used to grow, and are so popular to-day. We give very liberal packets for the money probably double what some seedmen give.

Annuals-Bloom first year from seed and plant dies after one season.

Biennials-Bloom second year from seed and plant dies after second year.

Perennials-Bloom second year from seed and plant lives and blooms for several years.

Tender-Means plant will not stand the least frost.

Half-Hardy-Means plant will stand a jittle frost and needs protection.

Hardy--Means plant will stand considerable frost. 
AGERATUM (Floss Flower.)

A hardy annual of easy culture . Especially valuable for bedding as it is literally covered with blossoms all summer. Sow the seed early in spring, either in boxes to transplant, or out of doors and thin to four or six inches.

Best mixed varieties, .

ALYSSUM, Sweet.

A fragrant hardy annual, bearing spikes of small, white flowers in great profusion throughout the summer and autumn. Useful for borders or early bedding. Sow the seed early in spring.

Little Gem, 3 to 4 inches high,

Per ounce, 20 cts.

White Carpet,

Per ounce, 25 cts.

ANTIRRHINUM (Snap Dragon.)

A half-hardy perennial, growing from 6 inches to 2 feet tall. Flowers are oddly shaped and apparently closed, but by pressing the sides together can be made to open like a dog's mouth.

Extra Choice Mixed,

Per ounce, 25 cts.

\section{ASTERS.}

A popular half-hardy annual, growing from one to two feet high. The best method of culture is to sow the seed in boxes in late winter and transplant about May 1st. The seed can be sown, however, in rows where the plants are to remain, thinning them 10 to 12 inches apart.

Queen of Spring, (white), .

Choice Tall Mixed, best varieties, . . . . . . .

\section{BACHELOR'S BUTTON.}

A hardy annual of easy culture. Sow the seed early in spring where it is to remain and thin to 3 or 4 inches.

Finest Mixed Varieties,

\section{CALLIOPSIS.}

A half-hardy annual, growing 3 feet high and valuable for bright bedding effect or for cut flowers.

Grandiflora,

\section{CANDYTUFT}

A hardy annual of easy culture, growing 10 to 18 inches high. The flowers are white and borne on various long spikes, forming very large heads, and are used for bedding or cut flowers.

Giant Hyacinth Flowered,
Pkt CARNATION

Pkt.

A half-hardy perennial, used generally for greenhouse trade in winter and for a general garden favorite in summer. Sow the seed early in the year in hotbed and transplant about April 15th.

Margarita Choicest Mixed,

\section{CENTAUREA.}

A hardy annual, growing $1 \frac{1 / 2}{2}$ to 2 feet high, bearing beautiful large flowers resembling sweet Sultan, but with a large petal margin around the blossom, sow seed early and transplant.

Imperialis Choice Iixed.

\section{CLARIKIA.}

Hardy annual of east culture about 18 inches high, flowering in great profusiun, seed sown in fall will give blossoms in spring, and can be sown most any time.

Finest Mixed,

\section{COCKSCONTs.}

A half-hardy annual, growing 6 to 8 inches high, bearing a wide wary blossom that resembles a cock's comb. Brilliant colors and fine for massing or border work.

Choicest Dwarf, mixed varieties,

\section{Cosyos.}

A tender annual, with fine cut feathery foliage and large feathery blossoms. Grows 4 to 6 inches high and blooms late in fall. Sow about May 1st and transplant in late May or June.

Choice Mixed Varieties.

DAHLIA.

A well known and popular late summer and autumn flowering plant. Seed may be sown early in hot bed and plants transplanted in May after all danger of frost is over. By sowing the seed early the plants may be made to bloom the first year.

Single (extra clioice mixed), . . . . . .10

Double (large flowering, finest mixed), . .15

\section{DIANTHUS (Pinks.)}

Hardy annual about one foot high and bearing beautifully colored single and double blossoms in profusion all summer. Sow seed early in boxes and transplant, or sow in rows where the plants are to remain and thin.

Splendid Mixed Varieties, . 


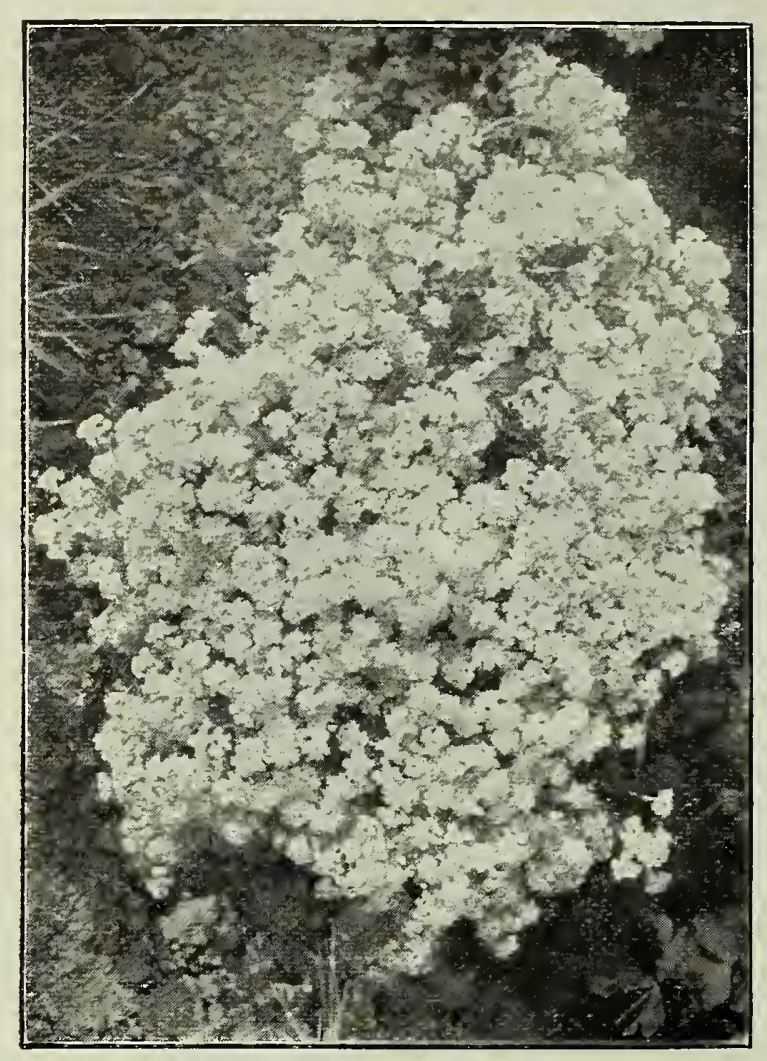

ALYSSUM

(See page 25)

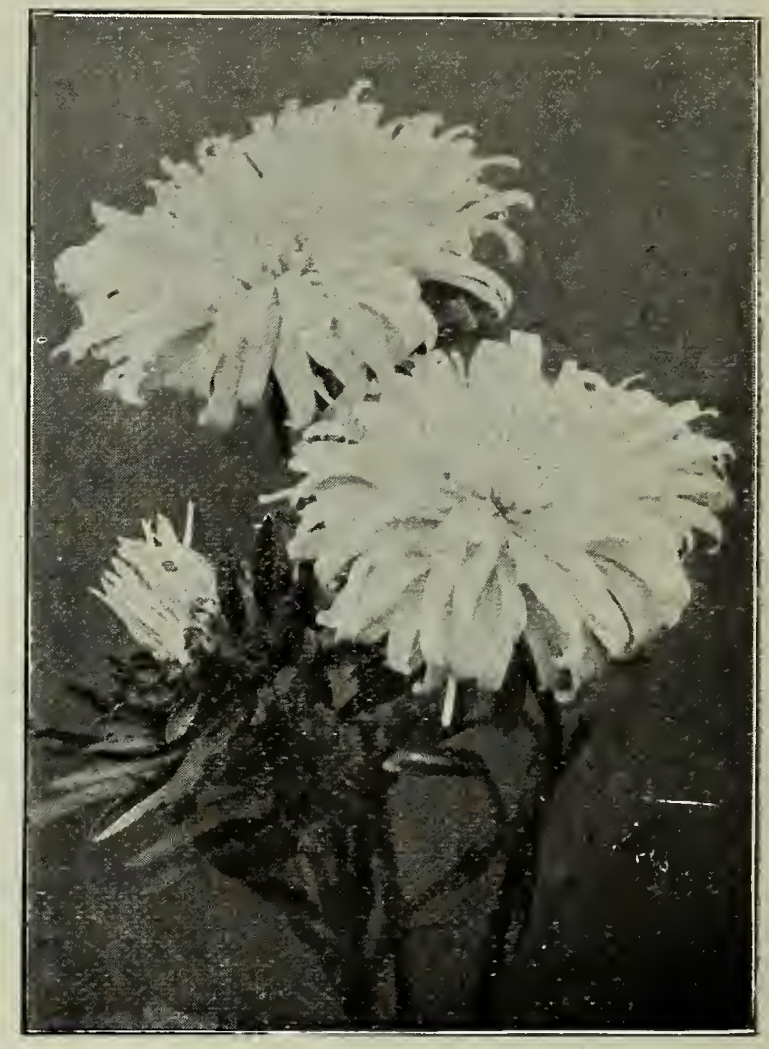

ASTER

(See page 25)

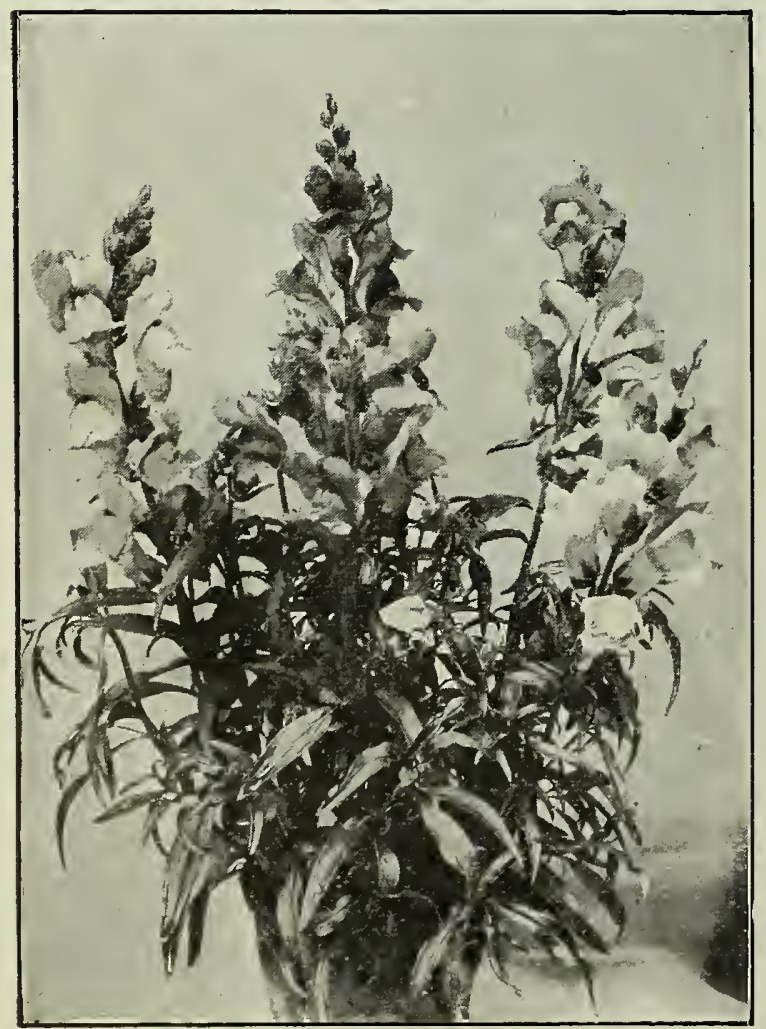

ANTIRRHINUM See page 25)

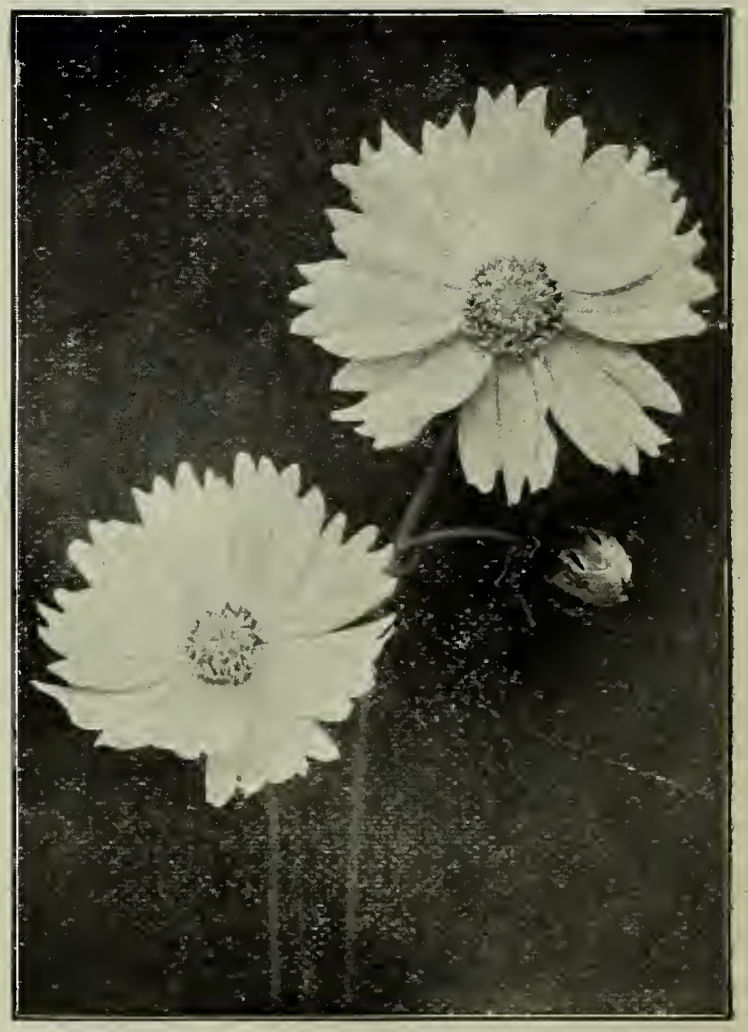

CALLIOPSIS

(See page 25) 


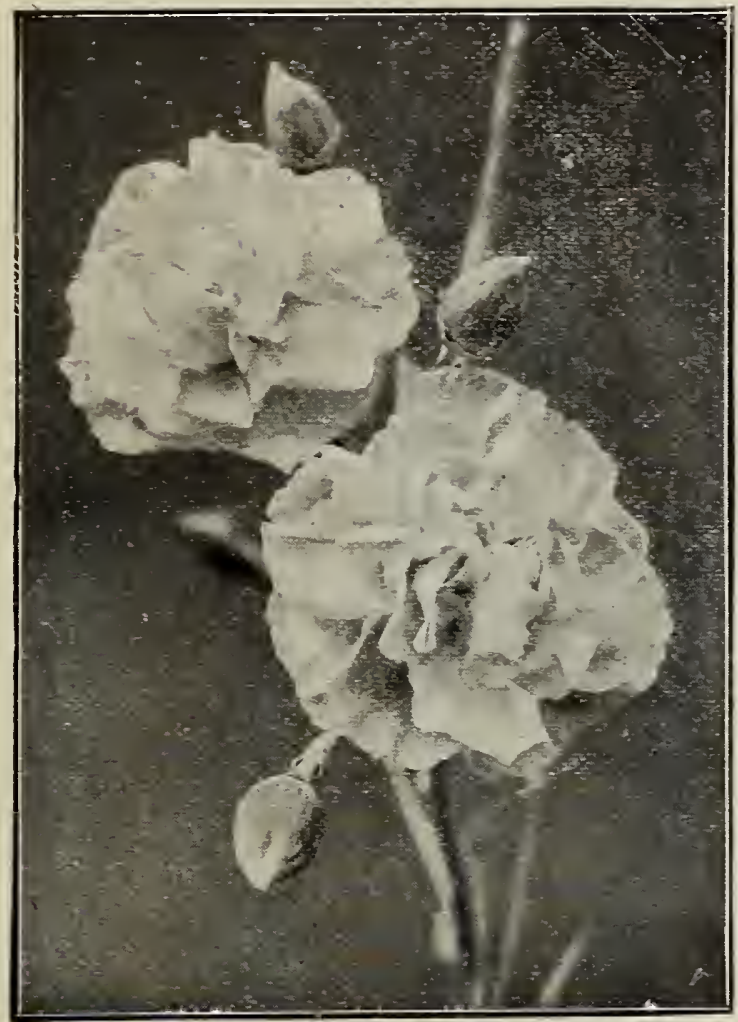

CARNATION

(See page 25)

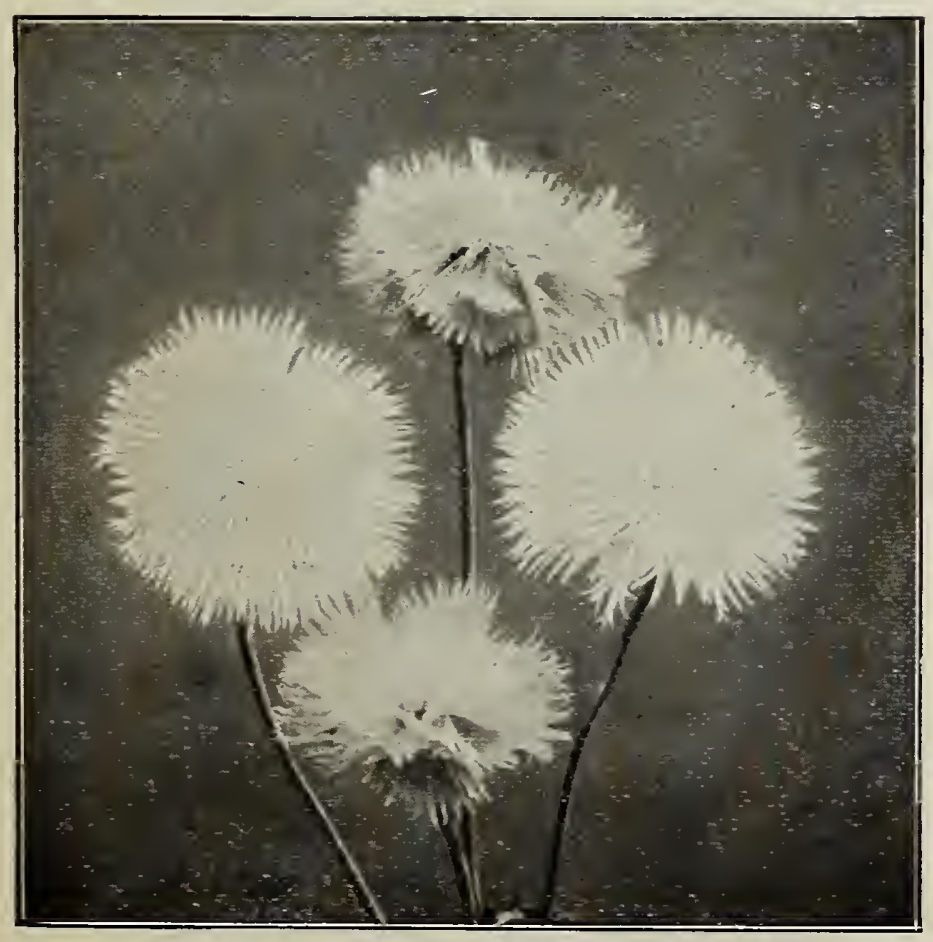

CENTAUREA

(See page 25)

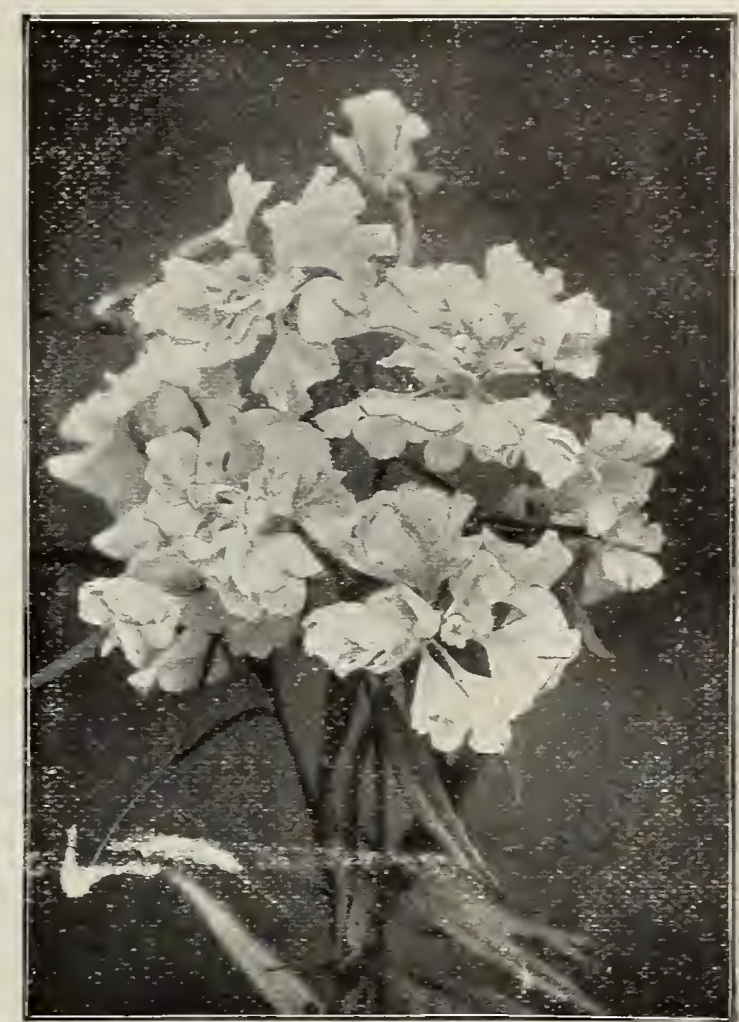

CLARKIA

(See page 25)

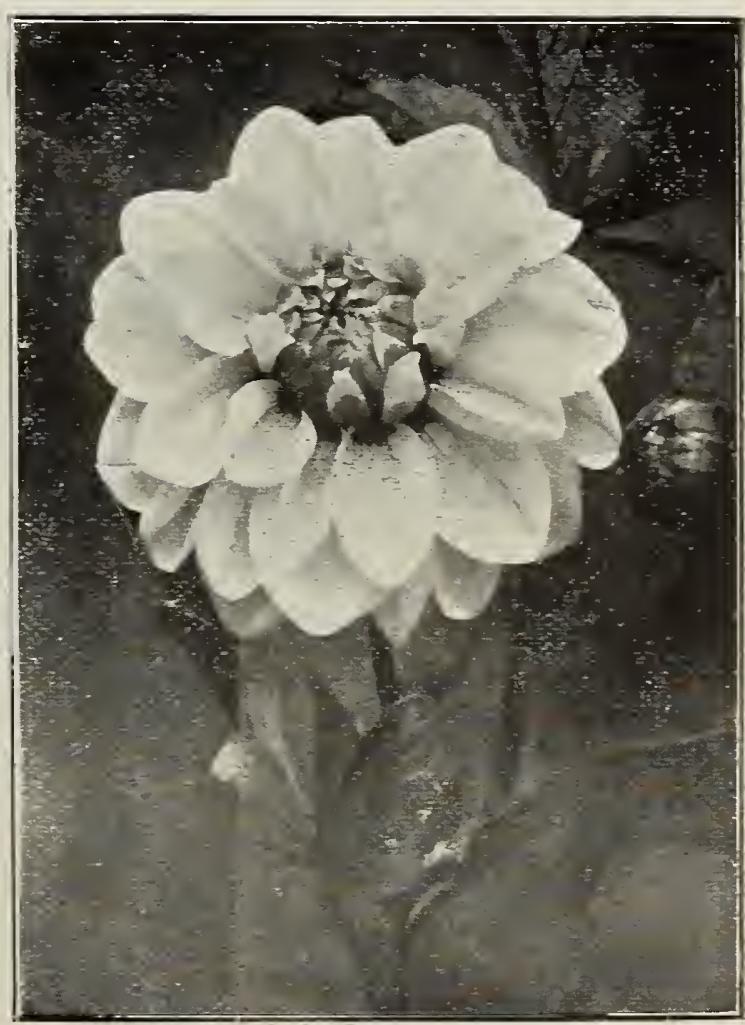

DAHLIA

(See page 25) 
DIGITALIS. (Fox Glove).

A hardy perennial, blooming the second year from seed. Grows usually about $31 / 2$ feet high. The bell-shaped flowers are borne on long spikes and in shades of purple, lavender, rose and white. All spotted lightly inside the blossom. Thrives best in cool, shady locations.

Best Mixed Varieties,

\section{GODETIA.}

Hardy annual of compact growth, 6 to 10 inches high, bearing a profusion of satin cupshaped flowers, valuable for bedding or massing. Sow seed early.

Duchess of Albany,

\section{HOIJYHOCK.}

A hardy perennial of upright, stately growth, 5 to 8 feet high. They make a fine row in the garden, or a fine background next to a building or high wall or fence.

Finest Double Mixed,

\section{MARIGOLD.}

A hardy annual shrub plant in dwarf and tall varieties, growing from 6 inches to 3 feet high. Foliage, bright green, deeply cut, and graceful. The flowers are various shades of yellow and brown. Tall varieties are valuable for large bedding or background work and the dwarf varieties for border.

Eldorado, mixed colors, (tall), . . . .05

Dwarf, gold striped, . . . . . .05

\section{MIGNONETTE.}

A hardy annual, growing 6 to 12 inches high and bearing pyramidal-shaped flower spikes, which are made up of thickly set flowerets; exceedingly fragrant. Grows easily from seed and can either be transplanted from boxes or sown in garden and thinned to 4 to 6 inches. Valuable for potting, bedding or bordering.

Large Flowering,

Machet (fine selected stock),

\section{NASTURTIUM.}

Tender annual in two distinct classes,

Dwarf and Tall or Climbing.

Dwalf (finest mixed colors), oz. $10 \mathrm{c} .1 / 4 \mathrm{lb}, 15 \mathrm{c}$. Tall (finest mixed colors), . oz. $10 \mathrm{c} .1 / 4 \mathrm{lb} .15 \mathrm{c}$.

\section{NICOTIANA.}

A half-hardy annual, growing about 3 feet high. Belongs to the tobacco family, has white blossoms, needs plenty of room.

Affinis,

\section{PANSY.}

A half-hardy perennial, growing 4 to 6 inches high. It thrives best in a moist, shady location and in rich loamy soll. Seed should be sown in autumn for early spring blossoms. While the plants carry over well with a little covering during the winter, it is best to plant the seed anew each year.

Large French Strain, choice mixture,

\section{PETUNIA.}

A tender perennial. Adapted for greenhouse and pot culture and for open air, succeeding well in most any rich soll. Abundance of brilliant flowers during the season.

Extra Choice Mixed,

\section{PHLOX DRUMMONDII.}

A hardy annual, growing from 6 to 10 inches high and bearing beautiful soft petaled and brilliantly colored, flowers all spring and summer. Fine for bedding. Sow seed about May 1st.

Choice Mixed,

\section{POPPY.}

A hardy annual, 3 to 5 feet high and bearing single and large double blossoms in bright colors. Sow seed in open ground where plants are to remain and thin to 6 or 12 inches.

White Swan, (a large double white flower), .05

The Shirley Mixed, (large single flower),

\section{SCABIOSA or Morning Bride.}

Also called Sweet Scabious, Old Maid's Pincushion, etc. A hardy annual, growing 8 inches to 2 feet high, and bearing heads of bright flowers on long slender stems. Very effective as a bedding plant, or for cut flowers.

Tall Mixed German Double, . . . .05

\section{SALPIGLOSSIS.}

A half-hardy annual, about 3 feet high, bearing trumpet shaped blossoms of rich shades and colors, valuable for bedding or massing also for cut flowers. Sow seed early and transplant or thin to 6 or 8 inches.

Choice Mixed. 


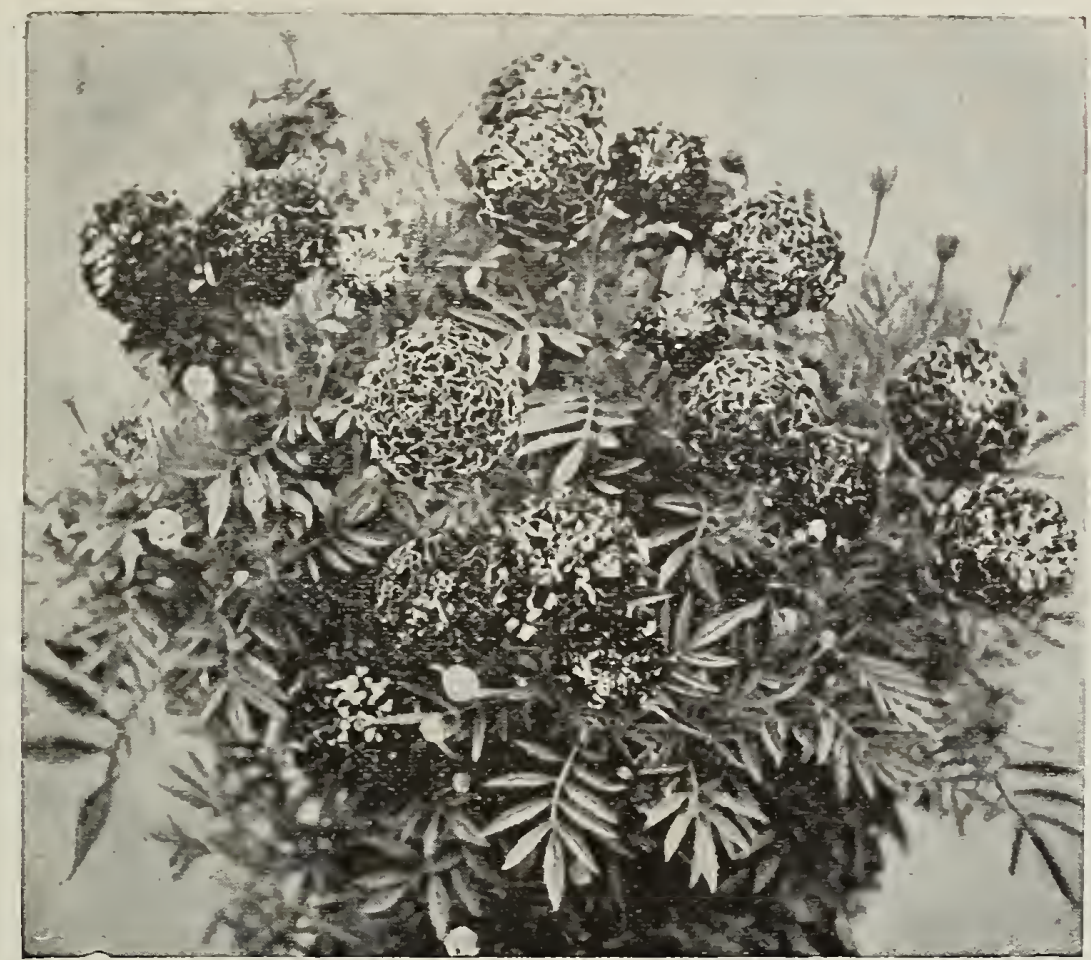

MARIGOLD

(See page 28.)

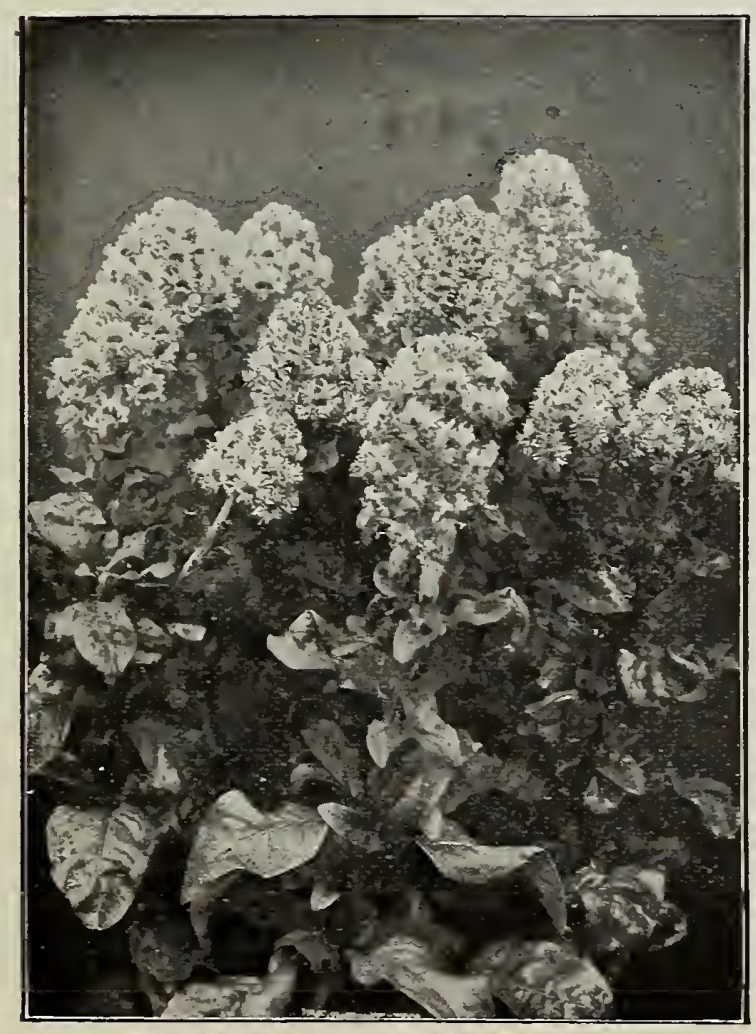

MIGNONETTE

(See page 28)

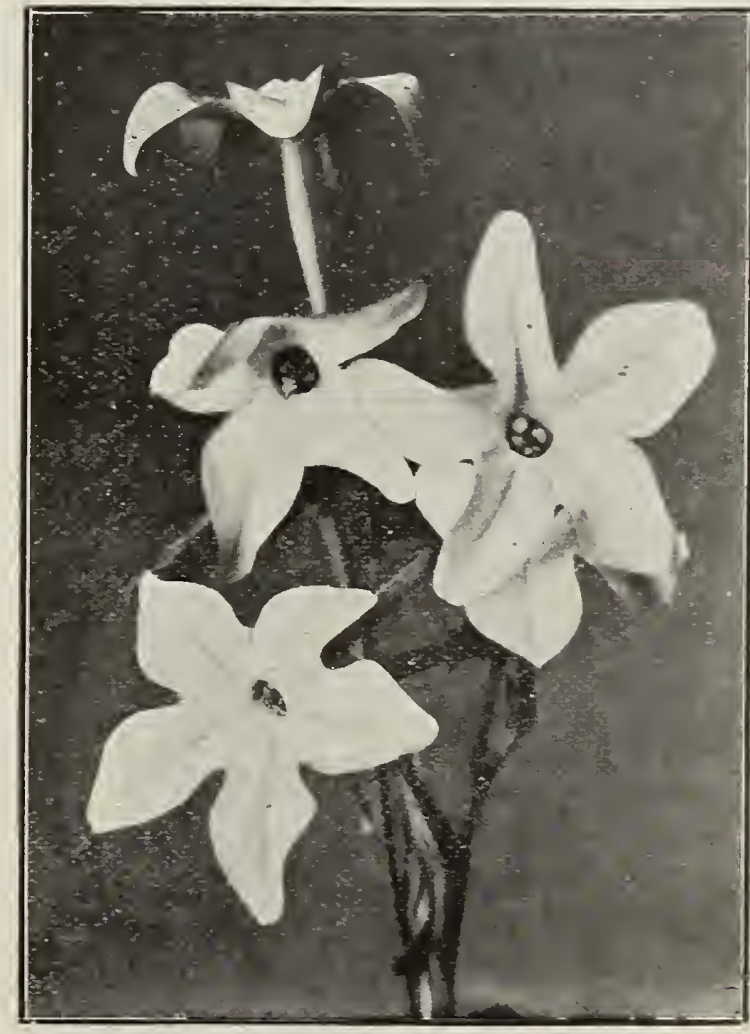

NICOTIANA

(See page 28) 


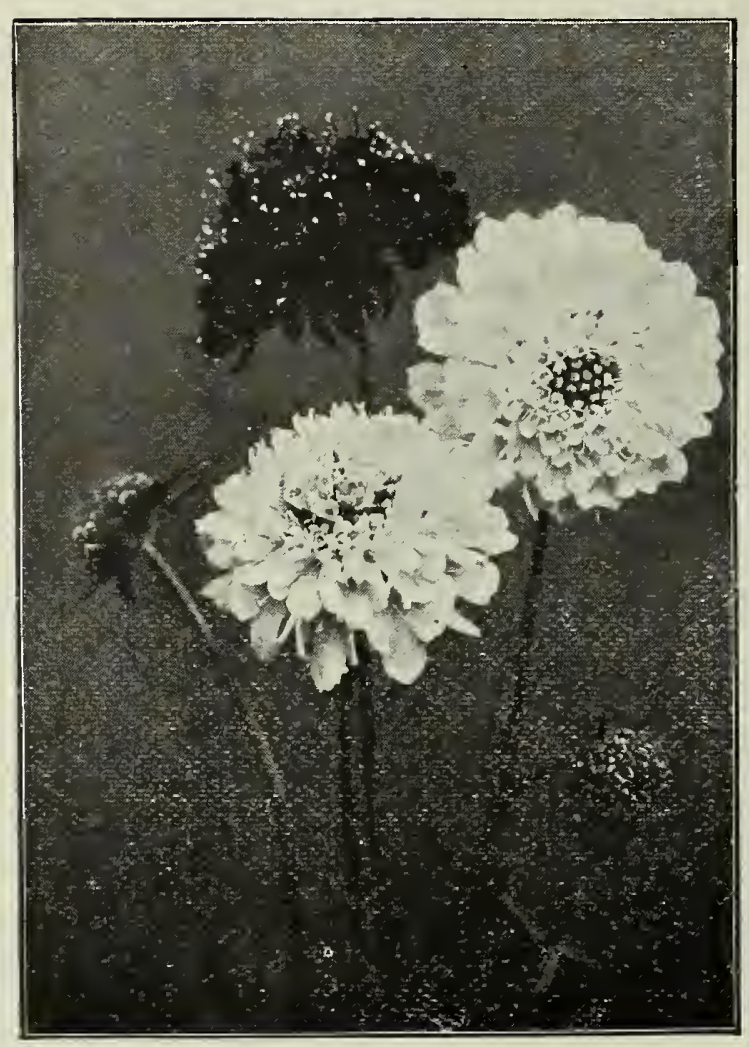

SCABIOSA

(See page 28)

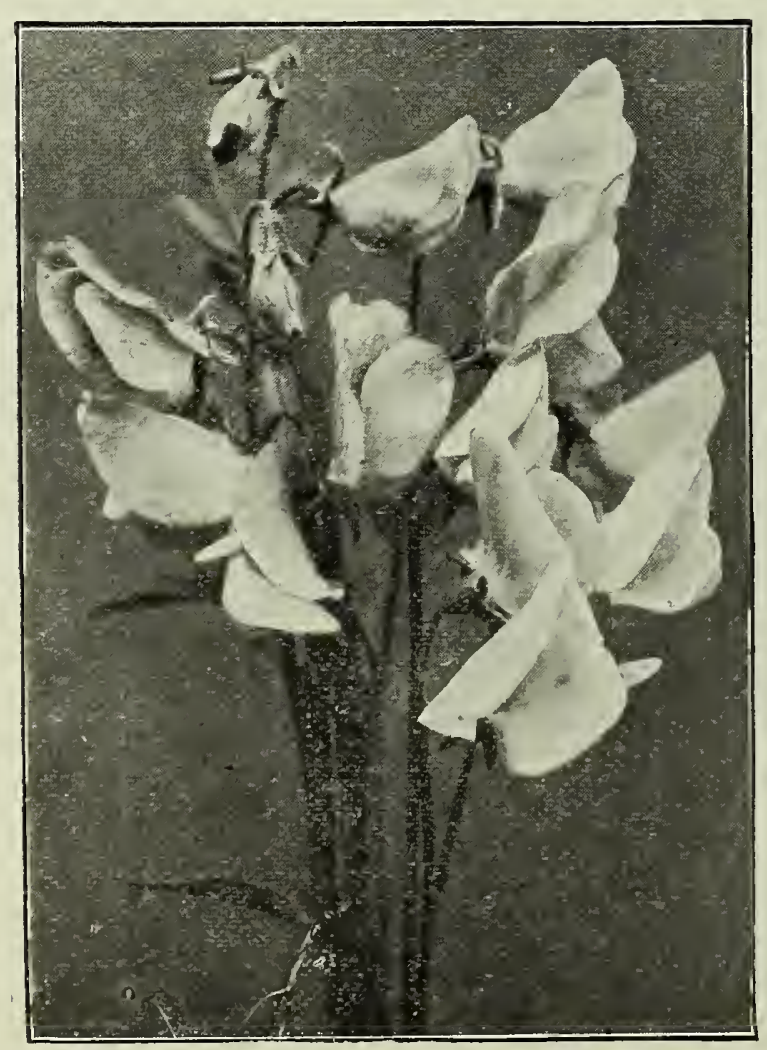

SIVEET PEAS

'See page 31)

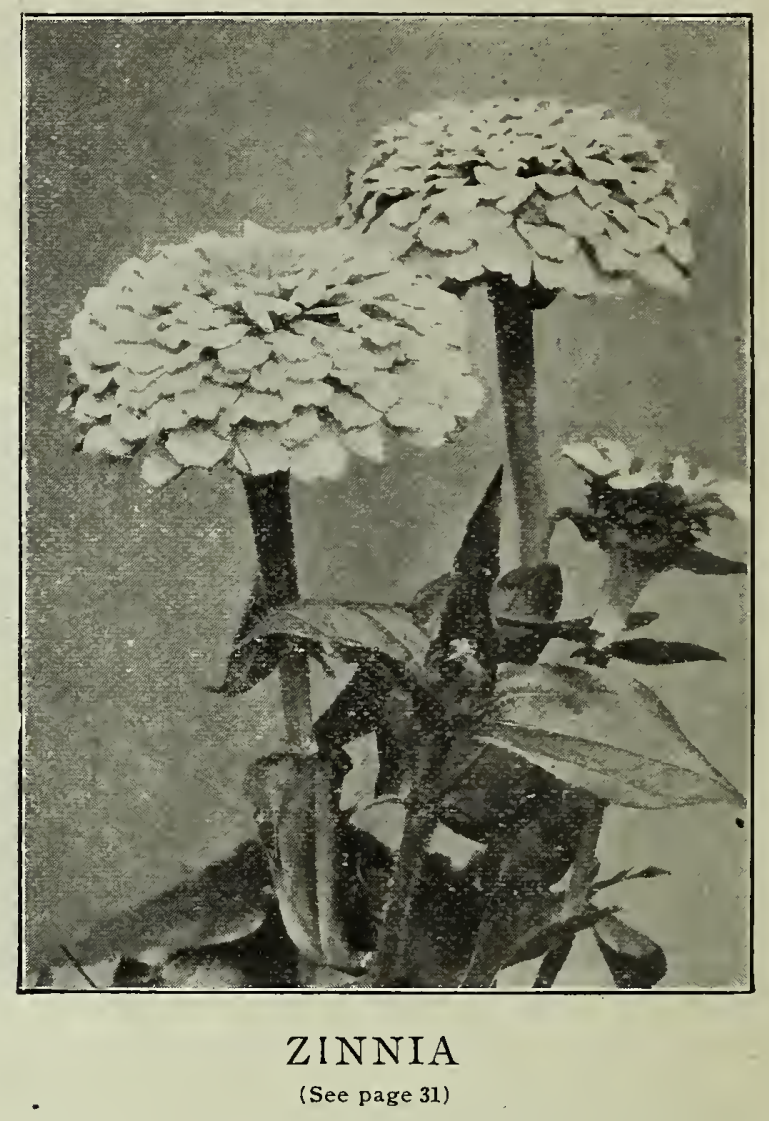

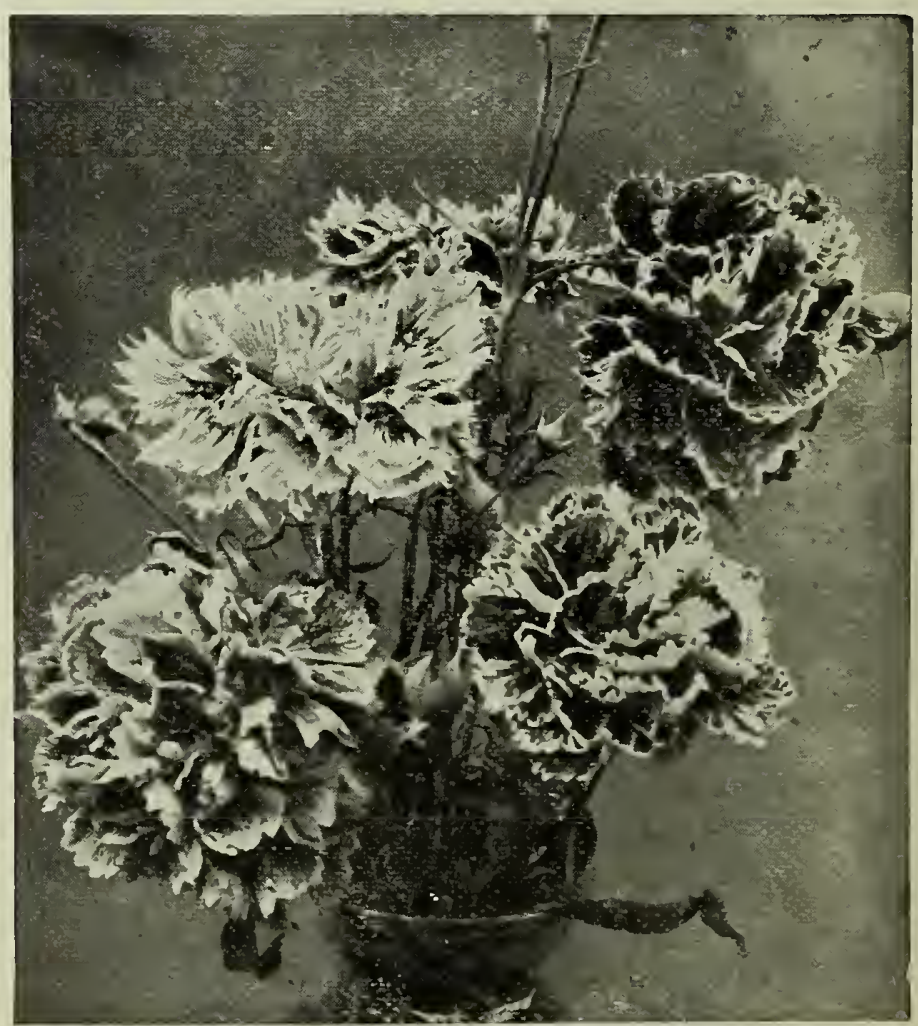

DIANTHUS

(See page 25) 
SALVIA. (SCARLET SAGE.)

A tender perennial, blooming the first season from seed and growing 2 to 3 feet high. The blossoms are borne on long stems or spikes and are fragrant. The plant forms a bunch filled with bright scarlet blossoms.

Splendens,.

\section{SIVEET PEAS.}

The Sweet Pea is a climbing annual and hardy. This popular flower is of the easiest culture and well adapted to most any climate. The seed should be sown early in the spring in a drill 4 to 6 inches deep, dropping three or four seeds every four inches and covering about one inch, working the soil around the plant as it comes up until it is on a level with the surface, this leaves the roots down deep enough not be so affected by dry weather.

Sweet Peas require an abundance of water and an open location. The water should be applied at the roots and the vines should not be sprinkled. A trellis of brush or chicken wire is necessary.

Apple Blossom; crimson, pink and white shaded.

Aurora; orange, rose striped or white.

Blanche Burpee; pure white, (white seeded)

Countess of Cadogan; purple changing to lilac and blue.

Countess of Radnor; lavender.

Emily Eckford; rose, lilac and blue.

Fascination; standard lilac, wings tinged with lilac.

Her Majesty; rose crimson.

Hon. Mrs. E. Kenyon; large primrose.

Lady Grisel Hamilton; light shaded lavender.
Lottie Eckford; white shaded lilac and blue.

Lovely; deep pink, shading to light pink.

Miss Wilmot; large orange, pink.

Navy Blue; navy and light blue.

Othello; deep maroon.

Prima Donna; pure pink.

Prince of Wales; purple wings, blue striped or white.

Sadie Burpee; white buds tinged with pink.

Salopian; bright red.

Venus; light pink and buff blended.

$\begin{array}{lllr} & \text { oz. } & \text { I// th } & \text { lb. } \\ \text { Price, any above variety, } & 8 \mathrm{c} . & 15 \mathrm{c} . & 40 \mathrm{c} . \\ \text { Finest Mixed Colors, } & 5 \mathrm{c} . & 15 \mathrm{c} . & 25 \mathrm{c} . \\ \text { Eckford's Superb or Mixed, } & 5 \mathrm{c} . & 15 \mathrm{c} . & 30 \mathrm{c} .\end{array}$

\section{SWEET WILLIAMS.}

A hardy perennial, blooming the second year from seed. Grows 1 to 2 feet high and bears its flowerets in clusters at end of a stiff stem. The individual flowers are handsomely colored and marked. It makes a beautiful bedding plant, and is of easy culture.

Double Finest Mixed, . . . . . .10

\section{ZINNIA.}

A half-hardy annual, growing from 1 to 2 feet high. Blossoms are very double and while the stems are stiff they make an excellent bouquet flower. The colors are in great variety and very bright. Probably no flower has such an assortment of shades, tints and colors, and no bedding plant is more effective for a brilliant show. Sow in boxes early and transplant.

Double Fine Mixed, . . . . . . . . 55 


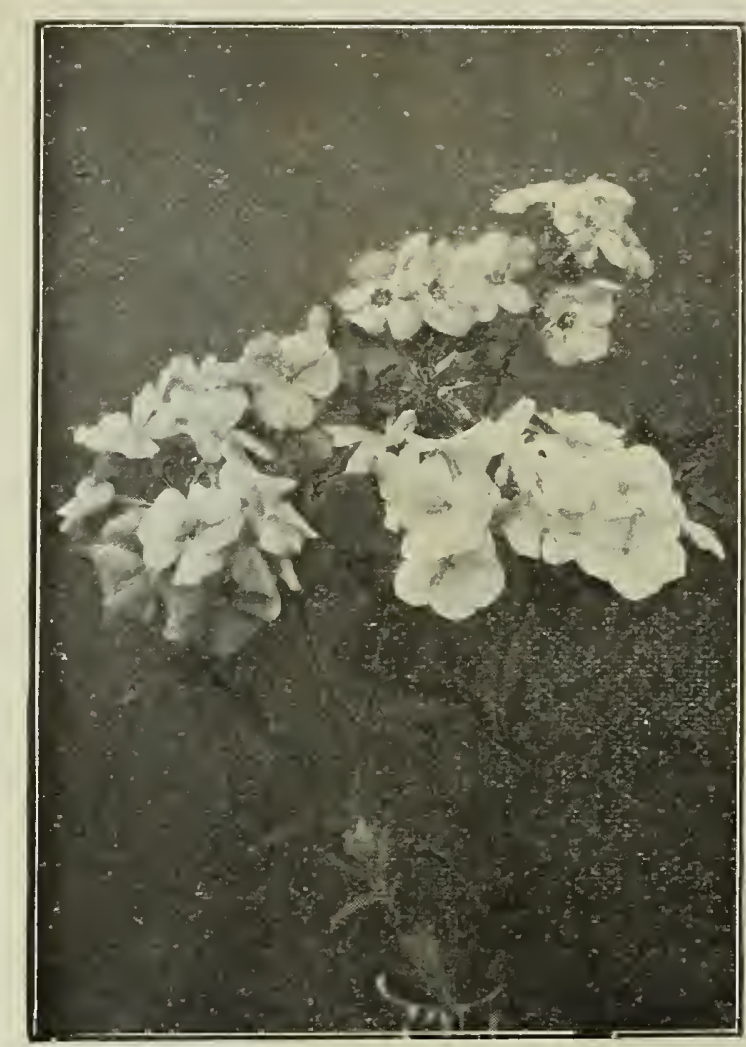

PHLOX

(See page 28)

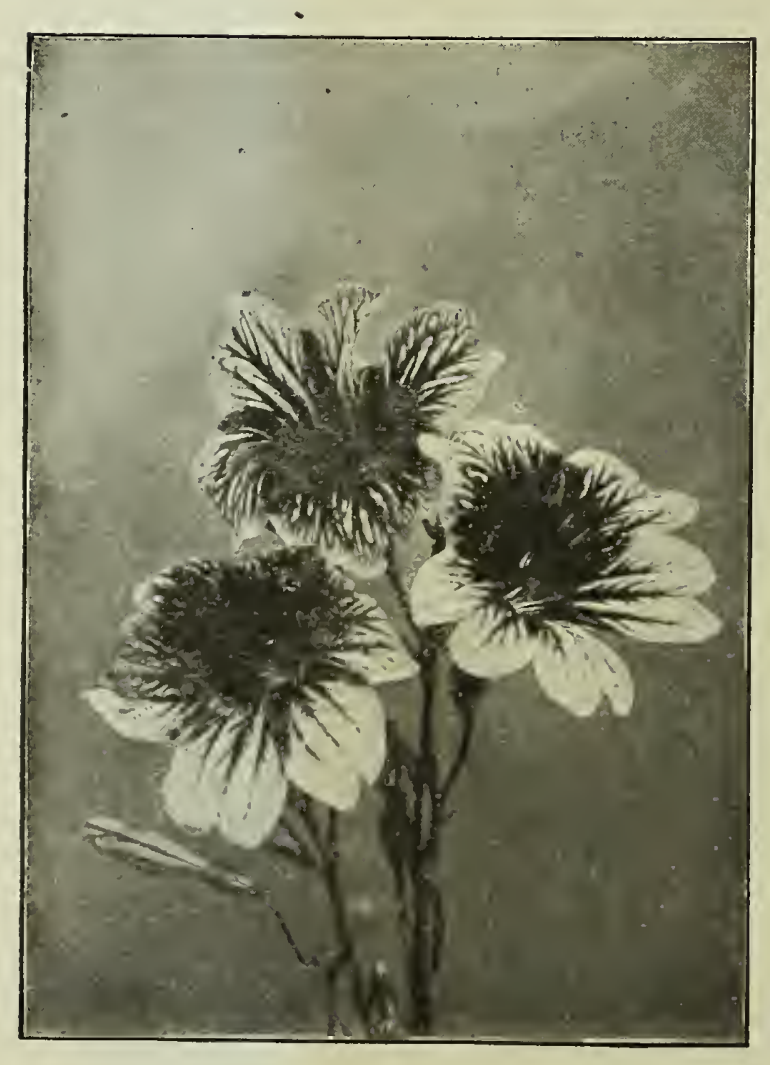

SALPIGLOSSIS

(See page 28)

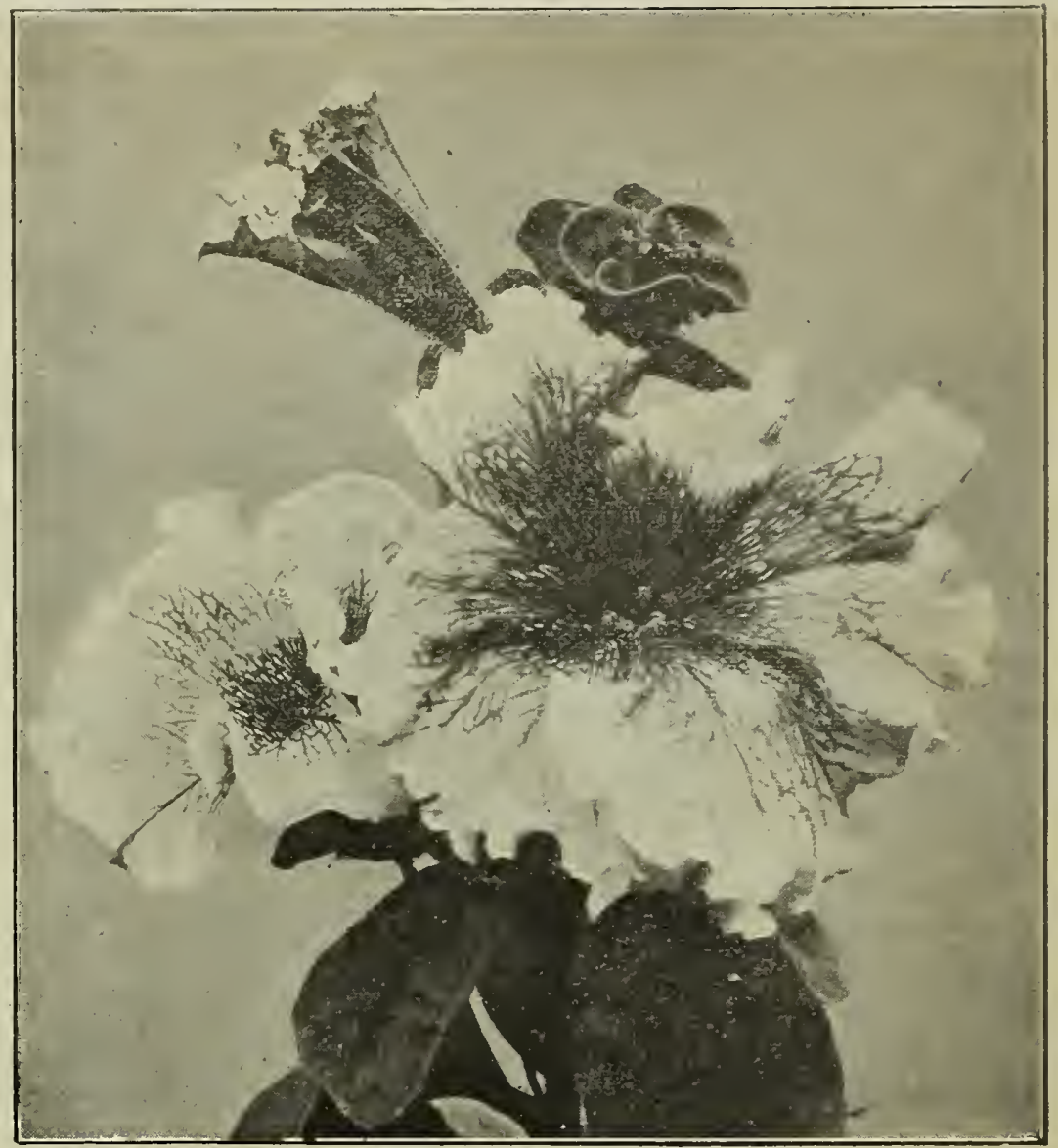

PETUNIA

(See page 28)

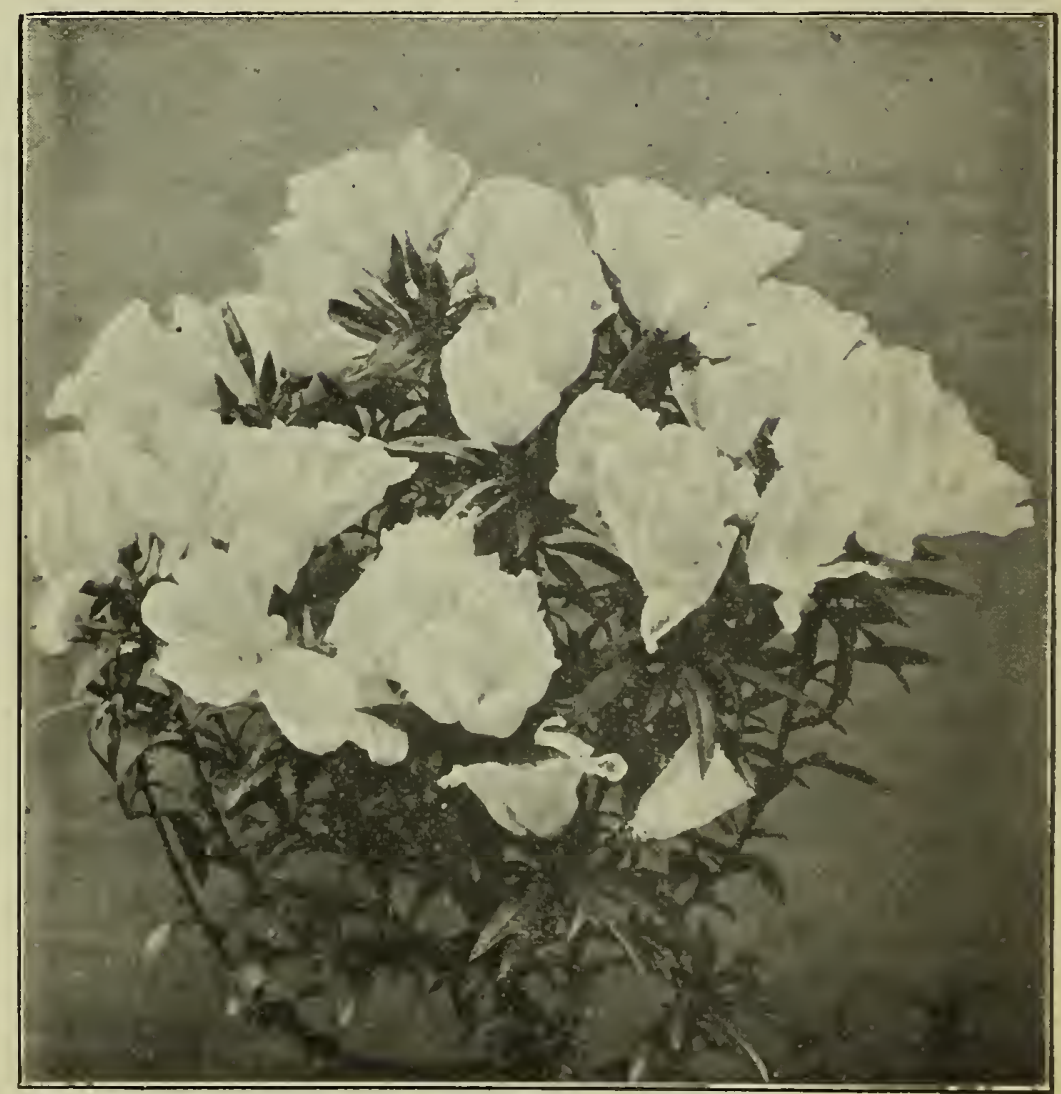

GODETIA

(See page 28) 


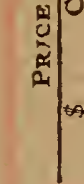

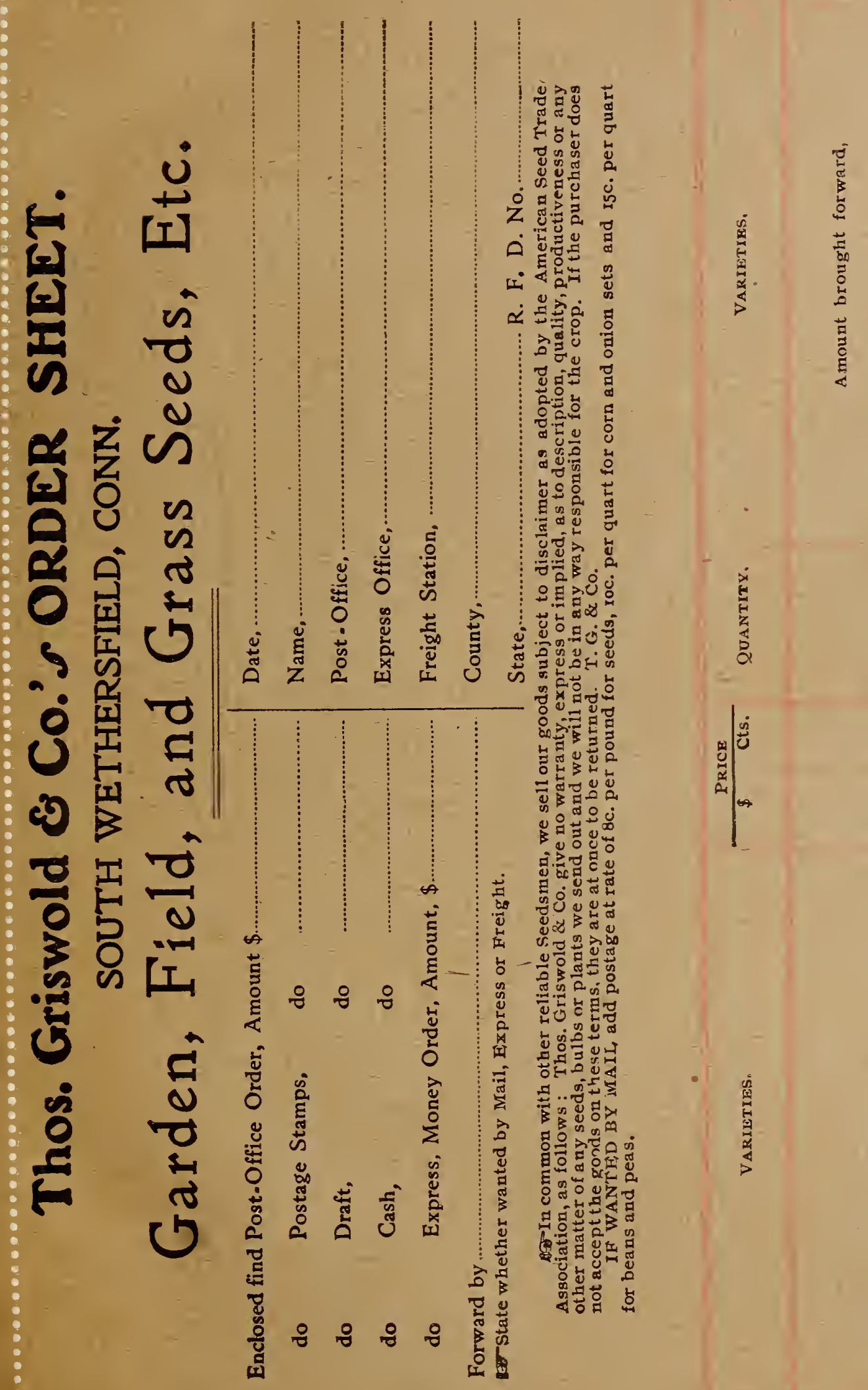

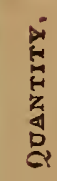



We Import most of our Flower Seed and think they are better than the American grown. 
The members of our firm are practical business men, born and brought up on seed farms, and the growing and care of seeds has been our life business.

By sending us your order you get fresh seeds and save dealers' profits. 